\title{
SCYL2 Protects CA3 Pyramidal Neurons from Excitotoxicity during Functional Maturation of the Mouse Hippocampus
}

\author{
Sebastien Gingras, ${ }^{1}$ Laurie R. Earls, ${ }^{2}$ Sherie Howell, ${ }^{3}$ - Richard J. Smeyne, ${ }^{2}$ Stanislav S. Zakharenko, ${ }^{1}$ \\ and ${ }^{-S t e p h a n e ~ P e l l e t i e r}{ }^{2}$ \\ Departments of 'Immunology, ${ }^{2}$ Developmental Neurobiology, and ${ }^{3}$ Biochemistry, St. Jude Children's Research Hospital, Memphis, Tennessee 38105
}

\begin{abstract}
Neuronal death caused by excessive excitatory signaling, excitotoxicity, plays a central role in neurodegenerative disorders. The mechanisms regulating this process, however, are still incompletely understood. Here we show that the coated vesicle-associated kinase SCYL2/CVAK104 plays a critical role for the normal functioning of the nervous system and for suppressing excitotoxicity in the developing hippocampus. Targeted disruption of $S c y l 2$ in mice caused perinatal lethality in the vast majority of newborn mice and severe sensory-motor deficits in mice that survived to adulthood. Consistent with a neurogenic origin of these phenotypes, neuron-specific deletion of $S c y l 2$ also caused perinatal lethality in the majority of newborn mice and severe neurological defects in adult mice. The neurological deficits in these mice were associated with the degeneration of several neuronal populations, most notably CA3 pyramidal neurons of the hippocampus, which we analyzed in more detail. The loss of CA3 neurons occurred during the functional maturation of the hippocampus and was the result of a BAX-dependent apoptotic process. Excessive excitatory signaling was present at the onset of degeneration, and inhibition of excitatory signaling prevented the degeneration of CA3 neurons. Biochemical fractionation reveals that Scyl2-deficient mice have an altered composition of excitatory receptors at synapses. Our findings demonstrate an essential role for SCYL2 in regulating neuronal function and survival and suggest a role for SCYL2 in regulating excitatory signaling in the developing brain.
\end{abstract}

Key words: apoptosis; CA3; CVAK104; excitotoxicity; hippocampus; SCYL2

Significance Statement

Here we examine the in vivo function of SCYL2, an evolutionarily conserved and ubiquitously expressed protein pseudokinase thought to regulate protein trafficking along the secretory pathway, and demonstrate its importance for the normal functioning of the nervous system and for suppressing excitatory signaling in the developing brain. Together with recent studies demonstrating a role of SCYL1 in preventing motor neuron degeneration, our findings clearly establish the SCY1-like family of protein pseudokinases as key regulators of neuronal function and survival.

\section{Introduction}

The SCY1-like (SCYL) family of protein pseudokinases, which includes SCYL1, SCYL2, and SCYL3, are thought to regulate pro-

Received May 20, 2014; revised June 2, 2015; accepted June 16, 2015.

Author contributions: S.P. and S.G. designed research; S.G., L.R.E., S.H., R.J.S., and S.P. performed research; S.P. contributed unpublished reagents/analytic tools; S.G., L.R.E., R.J.S., S.S.Z., and S.P. analyzed data; S.G. and S.P. wrote the paper.

This work was supported by National Institutes of Health Cancer Center CORE Grant CA21765, R01 MH095810, and MH097742 to S.S.Z.; the American Lebanese Syrian Associated Charities; and National Institutes of Health Grants R01 DK42932 and P01 HL53740 to Dr. James N. Ihle. We thank Dr. Vani Shanker for editing the manuscript; and the Animal Imaging Center, the Veterinary Pathology Core Laboratory, the Histology Laboratory, the Hartwell Center for Bioinformatics and Biotechnology, and the Genetics/Transgenic Core Unit for help with the generation and characterization of the mouse lines.

The authors declare no competing financial interests.

Correspondence should be addressed to Dr. Stephane Pelletier, Department of Immunology, St. Jude Children's Research Hospital, Memphis, TN 38105. E-mail: stephane.pelletier@stjude.org.

DOI:10.1523/JNEUROSCI.2056-14.2015

Copyright $\odot 2015$ the authors $\quad 0270-6474 / 15 / 3510510-13 \$ 15.00 / 0$ tein trafficking along the secretory pathway (Conner and Schmid, 2005; Düwel and Ungewickell, 2006; Borner et al., 2007; Burman et al., 2008, 2010; McMahon and Boucrot, 2011; Hamlin et al., 2014). Initially identified through subcellular proteomics as a component of the clathrin-coated vesicles (Wasiak et al., 2002), SCYL2, also known as the coated vesicle-associated kinase of 104 $\mathrm{kDa}$ (CVAK104), was later shown to interact with various core components of the clathrin machinery and proposed to regulate essential cellular functions, such as clathrin-mediated endocytosis (Conner and Schmid, 2005), targeting of membrane receptors for lysosomal degradation (Terabayashi et al., 2009) and/or sorting at the trans-Golgi network (Düwel and Ungewickell, 2006; Borner et al., 2007). Consistent with a role for SCYL2 in regulating essential cellular functions, morpholino-mediated downregulation of the $S c y l 2$ gene in Xenopus tropicalis was shown to cause severe developmental defects (Borner et al., 2007). 
To examine the in vivo function of SCYL2, we generated mice bearing null and conditional allele of $S c y l 2$. Here we report that Scyl2-deficient embryos developed normally, but the vast majority of Scyl2-deficien mice died rapidly after birth due to feeding problems. A small fraction of Scyl2-null mice survived to adulthood but exhibited growth retardation and severe sensory-motor deficits. Neuron-specific deletion of $S c y l 2$ recapitulated the perinatal lethal phenotype, albeit to a lesser extent, consistent with a neurogenic origin of the phenotype. Importantly, a larger fraction of neuron-specific mutant of Scyl2 survived the perinatal lethality and exhibited growth retardation and severe neurological disorders that were associated with the loss of several neuronal populations, most notably CA3 pyramidal neurons, through excitotoxicity, an apoptotic cell death triggered by excessive activation of calcium-permeable glutamate receptors (Choi, 1988; Olney, 1989, 1993; Gillessen et al., 2002). Our data reveal an unexpected role for SCYL2 in regulating excitatory signaling in vivo and for maintaining neuronal integrity.

\section{Materials and Methods}

Plasmid DNA constructs. All oligonucleotides used in this study were produced by the Hartwell Center for Bioinformatics and Biotechnology (St. Jude Children's Research Hospital). Generation of the plasmid pBR322-DTA (diphtheria toxin A) has been described previously (Pelletier et al., 2012). Plasmids PL452 and PL451 were obtained from Dr. Neil A. Copeland (National Cancer Institute) (Liu et al., 2003). The plasmid PL451-TK was generated by subcloning a DNA fragment containing the TK cassette into the BstBI sites of PL451. Plasmids encoding the FLP and Cre recombinases (pMC-Cre) were obtained from Klaus Rajewski (Immune Disease Institute, Boston). The Scyl2 targeting construct was engineered by using the gap-repair technology as described previously (Liu et al., 2003). Briefly, a $31 \mathrm{~kb}$ fragment containing genomic sequences of the $S c y l 2$ gene was subcloned by gap repair into pBR322-DTA. A first cassette containing the neomycin-resistance gene flanked by 2 loxP sites (i.e., PL452) was inserted in intron 3. After excising the neomycin cassette by using Cre recombinase, a single loxP site was left in intron 3. A second cassette, containing the neomycin resistance and thymidine kinase cDNAs flanked by 2 Frt sites and a second loxP site (PL451-TK), was inserted in intron 8 (see Fig. 1A). Locations of the loxP sites were chosen such that a null allele was generated after Cre recombination. The full-length cDNA encoding Scyl2 (IRAV4037878, NM_198021) was purchased from Open Biosystems. The sequence was verified by DNA sequencing (Hartwell Center for Bioinformatics and Biotechnology), and a FLAG epitope was added at its $\mathrm{N}$ terminus (N-FLAG) by using standard molecular biology techniques.

Mouse husbandry. All animals were housed in a facility accredited by the Association for Assessment and Accreditation of Laboratory Animal Care International and maintained in accordance with the National Institutes of Health Guide for the Care and Use of Laboratory Animals. All experiments involving animals were reviewed and approved by the St. Jude Children's Research Hospital Institutional Animal Care and Use Committee.

Generation of mice bearing conditional and null alleles of Scyl2. The Scyl2 gene was targeted in EmbryoMax mouse embryonic stem cell lines [Strain 129/svev (CMTI-1 cells, Millipore)], using the Scyl2 targeting construct. Positive clones were identified by Southern blotting of EcoRIdigested genomic DNA by using $5^{\prime}$ and $3^{\prime}$ external probes. To identify single recombination events, EcoRI-digested genomic DNA obtained from positive clones were also analyzed by Southern blotting using a neomycin probe. ES cell clones bearing the null (Scyl2-) or the conditional allele $(S c y l 2 f l)$ were generated by electroporating ES cell clones with plasmids encoding Cre or FLP. 1-(2-Deoxy-2-fluoro- $\beta$-Darabinofuranosyl)-5-iodouracil $(0.5 \mu \mathrm{M})$ was used as negative selection. Properly rearranged clones were identified by Southern blotting, using the $5^{\prime}$ and $3^{\prime}$ external probes and PCR. Two clones, one for each allele, were then injected into blastocysts. Blastocysts were implanted into $\mathrm{BALB} / \mathrm{c}$ recipient females to produce chimeras. Chimeras were crossed to
C57BL/6 mice (The Jackson Laboratory) to obtain heterozygous mice. Heterozygous mice were bred once to C57BL/6 mice, and their progeny was used for the heterozygous intercross. The NesCre+ mouse line (B6.Cg- $\mathrm{Tg}$ (Nes-Cre) $1 \mathrm{Kln} / \mathrm{J} \# 003771$ ) was purchased from The Jackson Laboratory. Mice bearing the conditional allele of Bax (Baxfl) have been described previously (Takeuchi et al., 2005).

PCR genotyping. Mouse genotypes were routinely determined by PCR on genomic DNA obtained from limb or tail biopsies. By using the primers, S2F01: 5'-AAATGTCTCTGTCGTGTTTATGTGA-3', S2R51: 5' GTTGGCAGCATGTTACTGTCACTCA-3', and S2R04: 5'-ACCTCT GAATTGTGCCTCTTCCTGA-3', bands of 354, 191, and 458 bp corresponding to the wild-type (WT) $(S c y l 2+)$, null allele (Scyl2-), and conditional allele $(S c y l 2 f l)$, respectively, were obtained. Mice bearing the NesCre + locus were genotyped by PCR according to The Jackson Laboratory protocol (http://jaxmice.jax.org/strain/003771.html). Mice bearing the conditional allele of Bax were genotyped as described previously (Takeuchi et al., 2005).

Generation of SCYL2 antibody. A peptide corresponding to the amino acids 24-39 (MGNPVTREFDVGRHIA [serum 7649]) of SCYL2 was synthesized by the Hartwell Center for Bioinformatics and Biotechnology and conjugated to glutaraldehyde-activated keyhole limpet hemocyanin. The keyhole limpet hemocyanin-conjugated peptide was then used to immunize rabbits (Rockland Immunochemicals). The anti-SCYL2 antibody was affinity purified over the corresponding peptide, and its selectivity was tested by Western blotting of brain extracts obtained from $S c y l 2^{+/+}, S c y l 2^{+/-}, S c y l 2^{-/-}, S c y l 2^{+/ f l}$, and $S c y l 2^{f l / f l}$ mice. There was no cross-reactivity with other SCYL proteins when these antisera were tested against other SCYL family members by using RNAi-mediated knockdowns. This antibody was functional for Western blotting applications only. For immunofluorescence and confocal microscopy, the antiSCYL2 antibody from Proteintech Group (12325-1-AP) was used.

Commercial antibodies. The following antibodies were used: anticlathrin heavy chain antibody (anti-CHC; BD Biosciences, 610500), antiCHC antibody (X-22, Abcam, ab2731), anti- $\alpha$-adaptin (BD Biosciences, 610502), anti- $\beta 2$-adaptin (BD Biosciences, 610382), anti- $\gamma$-adaptin (BD Biosciences, 36120 ), anti- $\beta$ NAP ( $\beta 3$-adaptin, BD Biosciences, 51 9002031), anti-p47 ( $\mu 3$-adaptin, BD Biosciences, 51-9002064) anti- $\mu 2-$ adaptin (AP50, BD Biosciences, 611351) anti- $\delta$-adaptin (BD Biosciences, 51-9001906), anti-NMDA receptor 1 (NR1, Sigma, G8913), anti-NR2A (Sigma, G9038), anti-Grik4 (anti-KA1 receptor, Sigma, PRS4391), antiGFAP (DAKO, Z0334), anti-c-Fos (Cell Signaling Technology, clone 9F6, 2250), anti-Iba1 (Wako, 019-19741), anti-cleaved-caspase 3 (Biocare, CP-229C), anti-BAX (Santa Cruz Biotechnology, sc-493), anti-amphiphysin (BD Biosciences, 51-9001902), anti-AP180 (BD Biosciences, 51-9001899), anti-Vti1b (BD Biosciences, 611405), antiPSD-95 clone D74D3 (Cell Signaling Technology, 3409), anti-PSD-95 clone 6G6-1C9 (Pierce, MA1-045), anti-synaptophysin (Millipore, AB1543P), anti-MPR300 D3V8c (Cell Signaling Technology, 14364), anti-EGFR antibody (Fitzgerald, 20-ES04), anti- $\beta$-actin (Sigma A5441), anti-rabbit IgG HRP-linked antibody (Jackson ImmunoResearch Laboratories, 111-035-003), anti-mouse IgG HRP-linked antibody (Jackson ImmunoResearch Laboratories, 115-035-174), AlexaFluor-568 donkey anti-mouse IgG $(\mathrm{H}+\mathrm{L})$ (Invitrogen, A10037), AlexaFluor-488 goat antirabbit IgG $(\mathrm{H}+\mathrm{L})$ (Invitrogen, A11008), and a biotinylated goat antirabbit antibody (Vector Laboratories, BA-1000). The monoclonal antibodies against the cation-dependent mannose 6-phosphate receptor (clone 22d4) and lysosomal membrane glycoprotein A (LAMP-1, 1D4B), developed by D. Messner and A. J. Thomas, respectively, were obtained from the Developmental Studies Hybridoma Bank, created by the $\mathrm{Na}$ tional Institute of Child Health and Human Development of the National Institutes of Health and maintained at the University of Iowa (Department of Biology, Iowa City, Iowa).

Grip strength. The inverted-grid test was used to assess neuromuscular function and muscular strength (Pelletier et al., 2012). Mice were placed on top of an elevated cage grid. The cage grid was inverted, and the time until the release of mice was measured.

Tail suspension test to assess depression-like behavior. Depression-like behavior was assessed in NesCre $+; S c y l 2+/ f l$ and NesCre $+; S c y l 2^{f l / f l}$ mice as described previously (Castagne et al., 2011). The duration of immo- 
bility was determined for the last $4 \mathrm{~min}$ of the 6 min tail suspension test. The strength of movement was evaluated by using the following scoring system: 0 , very weak or no movement; 1 , moderate movement; 2 , strong movement; and 3, very strong movement. Because only 6 Scyl $2^{-1-}$ mice were obtained from the $S c y l 2^{+/-}$intercross, behavioral despair and grip strength assays were performed only on neural-specific mutants.

MRI. MRI analyses were performed on 20-week-old male mutant $\left(S c y l 2^{-/-}, n=1\right.$ or NesCre $\left.+; S c y l 2^{f l / f l}, n=3\right)$ and control $\left(S c y l 2^{+/+}, n=\right.$ 1 or NesCre $+; S c y l 2+/ f l, n=3)$ mice. All mice were scanned on a 7 Tesla Bruker ClinScan animal MRI scanner (Bruker BioSpin MRI), using the Bruker $12 S$ gradient BGA12S and the 4-channel mouse surface coil for T2-weighted images in 2 directions. Sagittal scans were acquired at matrix $=320 \times 320$, field of view $=25 \times 25 \mathrm{~mm}$, slices $=17$ contiguous, thickness $=0.7 \mathrm{~mm}$, echo time $=39 \mathrm{~ms}$, and repetition time $=2579 \mathrm{~ms}$. Axial scans were acquired at matrix $=320 \times 320$, field of view $=25 \times 25$ $\mathrm{mm}$, slices $=16$ contiguous, thickness $=0.5 \mathrm{~mm}$, echo time $=42 \mathrm{~ms}$, and repetition time $=2620 \mathrm{~ms}$. Measurements were obtained from 3 control $\left(\mathrm{NesCre}+; S c y l 2^{+/ f l}\right)$ and 3 mutant $\left(\mathrm{NesCre}+; S c y l 2^{f l f l}\right)$ mice by using the Syngo fast view software (Siemens AG). Size ratios between mutant and control mice were determined by dividing the measurements in mutant mice (NesCre+;Scylf $f^{f l f l}, n=3$ ) by those in control mice $\left(\right.$ NesCre $\left.+; S c y l 2^{+/ f l}, n=3\right)$.

Electrophysiology. Acute transverse hippocampal slices $(400 \mu \mathrm{m})$ were prepared as previously described (Bayazitov et al., 2007). Briefly, mouse brains were quickly removed and placed in cold $\left(4^{\circ} \mathrm{C}\right)$ dissecting ACSF containing $125 \mathrm{~mm}$ choline- $\mathrm{Cl}, 2.5 \mathrm{~mm} \mathrm{KCl}, 0.4 \mathrm{~mm} \mathrm{CaCl}_{2}, 6 \mathrm{~mm} \mathrm{MgCl}_{2}$, $1.25 \mathrm{~mm} \mathrm{NaH}_{2} \mathrm{PO}_{4}, 26 \mathrm{~mm} \mathrm{NaHCO}_{3}$, and $20 \mathrm{~mm}$ glucose (285-295 mOsm) under $95 \% \mathrm{O}_{2}$ and $5 \% \mathrm{CO}_{2}$. After dissection, slices were incubated for $1 \mathrm{~h}$ in ACSF containing $125 \mathrm{~mm} \mathrm{NaCl}, 2.5 \mathrm{~mm} \mathrm{KCl}, 2 \mathrm{~mm} \mathrm{CaCl}_{2}$, $2 \mathrm{~mm} \mathrm{MgCl}_{2}, 1.25 \mathrm{~mm} \mathrm{NaH}_{2} \mathrm{PO}_{4}, 26 \mathrm{~mm} \mathrm{NaHCO}_{3}$, and $10 \mathrm{~mm}$ glucose (285-295 mOsm) under $95 \% \mathrm{O}_{2}$ and $5 \% \mathrm{CO}_{2}$ at room temperature and then transferred into the submerged recording chamber and superfused $(2-3 \mathrm{ml} / \mathrm{min})$ with warm $\left(30^{\circ} \mathrm{C}-32^{\circ} \mathrm{C}\right) \mathrm{ACSF}$. The field recordings were performed by using a setup with 8 submerged recording chambers (Campden Instruments). The fEPSPs were recorded from the CA1 stratum radiatum by using an extracellular glass pipette (3-5 M $\Omega$ ) filled with ACSF. Schaffer collateral/commissural fibers in the stratum radiatum were stimulated with a bipolar tungsten electrode placed 200-300 $\mu \mathrm{m}$ away from the recording pipette.

Histologic and immunohistochemical analyses. Immediately after being killed, adult mice were perfused with $10 \%$ buffered formalin (Thermo Scientific) through the left cardiac ventricle. The brain and spinal cords of perfused mice were postfixed by immersion in 10\% buffered formalin for at least $24 \mathrm{~h}$ before being further processed. Tissues were embedded in paraffin, sectioned at $4 \mu \mathrm{m}$, mounted on positively charged glass slides (Superfrost Plus, Fisher Scientific), and dried in a $60^{\circ} \mathrm{C}$ oven for $20 \mathrm{~min}$. Immunohistochemical analysis was performed by the polymeric biotinfree HRP method on a BOND-MAX stainer (Leica Microsystems). Tissue sections were placed in the automated BOND-MAX stainer and pretreated with enzyme-induced epitope retrieval for $8 \mathrm{~min}$, followed by incubation with the primary antibodies. Primary antibody binding to tissue sections was visualized by using the Bond Polymer Refine Detection kit (Leica Microsystems), with 3,3'-diaminobenzidine as the chromogenic substrate and a light hematoxylin counterstain.

Immunofluorescence staining. Immunofluorescence staining of formalinfixed tissues was performed according to the Cell Signaling Technology Technology protocol (http://www.cellsignal.com/support/protocols/IF. $\mathrm{html}$ ), using the citric acid-based ( $\mathrm{pH} 6.0$ ) antigen unmasking solution (H-3300, Vector Laboratories).

TUNEL assays. TdT-mediated dUTP-biotin nick end labeling (TUNEL) assays were performed by using the Dead End kit (catalog \#PRG7130, Promega) with the following modifications: Tris-buffered saline with Tween 20 buffer (catalog \#TA-999-TT, Lab Vision) was used for all washes, proteinase K (DAKO, S3020, $10 \mathrm{~min}$ ) was substituted for the kit proteinase $\mathrm{K}$, endogenous peroxidases were blocked for $5 \mathrm{~min}$ with $3 \% \mathrm{H}_{2} \mathrm{O}_{2}$ (Humco), and counterstaining was done with dilute hematoxylin (1:15, 3 min, catalog \#TA-125-MH, Lab Vision). Slides were then dehydrated and overlaid with coverslips. All steps of the protocol were performed on the Lab Vision autostainer at room temperature.

Cellularity. The cellularity of the hippocampal dentate gyrus (DG), CA1 area, and CA3 area was quantified by using a light microscope and the ImageJ software version 1.42q (http://rsbweb.nih.gov/ij/) on hematoxylin and eosin-stained sections. The number of clearly defined nuclei per $0.0165 \mathrm{~mm}^{2}$ in these areas was counted from 15 different images obtained from 3 mice per group. To quantify pyknotic cells, the number of cells with pyknotic nuclei per $0.0165 \mathrm{~mm}^{2}$ in the CA3 area was counted from 15 different images obtained from 3 mice per group. To quantify cleaved caspase-3-positive, TUNEL-positive, GFAP-positive, Iba1-positive, or c-Fospositive cells in the CA3 area, the number of cells per $0.0165 \mathrm{~mm}^{2}$ were counted from 6 to 15 different images obtained from 3 mice per group.

Tissue culture. HEK293T cells and SV40-transformed mouse embryonic fibroblasts (MEFs) were cultured in DMEM, high glucose, supplemented with FBS, L-glutamine, penicillin, and streptomycin as described previously (Pelletier et al., 2006). Hippocampal neurons were isolated from E18.5-P0 mouse brains and grown as described previously (Beaudoin et al., 2012).

Western blotting on mouse tissues. Mouse tissues were lysed in RIPA buffer (50 mm Tris-HCl, pH 8.0, $150 \mathrm{~mm} \mathrm{NaCl,} \mathrm{1 \%} \mathrm{NP-40} \mathrm{[Igepal-CA-}$ 630], $0.5 \%$ sodium deoxycholate, $0.1 \%$ SDS, and complete protease inhibitors and phosSTOP phosphatase inhibitors) (Roche). Western blotting was performed as described previously (Pelletier et al., 2006).

Immunoprecipitation, Western blotting, and LC-MS/MS. HEK293T cells were transfected using the $\mathrm{CaPO}_{4}$ precipitation method. Exponentially growing HEK293T cells were seeded at a density of $1.5 \times 10^{6}$ cells per $10 \mathrm{~cm}$ dish and transfected the next day with indicated amounts of plasmids. The next day, the medium was changed, and the cells were cultured for another $24 \mathrm{~h}$ before harvesting. The cells were then washed twice with ice-cold PBS and lysed in NP-40 lysis buffer $(50 \mathrm{~mm}$ Tris- $\mathrm{HCl}$, $\mathrm{pH}$ 7.4, $100 \mathrm{~mm} \mathrm{NaCl}, 50 \mathrm{~mm}$ sodium fluoride, $5 \mathrm{~mm}$ EDTA, $40 \mathrm{~mm}$ $\beta$-glycerophosphate, $1 \mathrm{~mm}$ sodium orthovanadate, $1 \% \mathrm{NP}-40$ [IgepalCA-630] supplemented with protease inhibitors [Complete; Roche]) at $4^{\circ} \mathrm{C}$ for $30 \mathrm{~min}$. Lysates were cleared by centrifugation at $12,000 \mathrm{rpm}$ in a refrigerated tabletop centrifuge (Baxter) at $4^{\circ} \mathrm{C}$ for $5 \mathrm{~min}$. Samples were then subjected to immunoprecipitation using M2-EZ-VIEW beads (Sigma) and eluted by the addition of 1 volume of $2 \times$ Laemmli buffer (Bio-Rad). Samples were run on 10\% SDS-PAGE and transferred to nitrocellulose or stained with Sypro-Ruby for mass-spectrometric analyses (LC-MS/MS). Western blot analyses were performed as described previously (Pelletier et al., 2006). Protein bands from the immune complexes resolved by SDS-PAGE were cut out, reduced and alkylated with iodoacetamide, and digested with trypsin. Mass spectrometric analysis was performed using an LTQ Linear Ion Trap Mass Spectrometer from Thermo Electron. Database searches were performed using LTQ.raw files in combination with the Mascot search engine (http://www. matrixscience.com). Protein/peptide assignments were made on the basis of MS/MS spectra. The Swissprot database (http://au.expasy.org) was used for protein identification.

Biochemical fractionation of brain tissues. Biochemical fractionation of brain tissues was performed as described previously (Hallett et al., 2008). Equal amounts of proteins $(20 \mu \mathrm{g})$ were resolved by SDS-PAGE and analyzed by Western blotting. Band intensities were quantified using National Institutes of Health ImageJ software version $1.42 \mathrm{q}$ (http://rsbweb.nih.gov/ij/).

Confocal microscopy. Immunofluorescence staining of SV40transformed MEFs and primary neuronal cultures was performed as described previously (Pelletier et al., 2005; Beaudoin et al., 2012). Cells were visualized using a Zeiss Observer. Z1 and images were captured with Slidebook6 acquisition and analysis software (3i Technologies). Colocalization was assessed by confocal microscopy along line segments intercepting at least 2 marker-positive structures (i.e., $\alpha$-adaptin-positive vesicles). A total of 20 segments from 5 cells/neurons were quantified. The percentage of marker-positive structures also containing SCYL2 was calculated for each segment, and values are reported as mean \pm SEM.

Lysosomal enzyme assays. Secretion of lysosomal enzymes was determined by measuring lysosomal enzyme activities in medium and cells as described previously (Köster et al., 1993; Kasper et al., 1996). Lysosomal acid 
phosphatase activity was determined by using $p$-nitrophenylphosphate as substrate as described previously (Gieselmann et al., 1984).

LAMP-1, MPR300, and MPR46 antibody endocytosis. Missorting of MPR300, MPR46, and LAMP-1 to the plasma membrane was assessed by MPR300, MPR46, and LMAP-1 antibody uptake as described previously (Meyer et al., 2000). Cells were incubated with the primary antibodies (1 $\mu \mathrm{g} / \mathrm{ml}$ ) for $2 \mathrm{~h}$ before fixing and processed for immunofluorescence staining as described above.

AlexaFluor-488-Transferrin (Tfn) endocytosis. Exponentially growing SV40-transformed Scyl2 $2^{+/+}$and Scyl2 ${ }^{-/-}$MEFs (3 independent lines for each genotype) were washed twice with serum-free medium (DMEM, high glucose, supplemented with L-glutamine, penicillin, streptomycin, and $0.1 \%$ BSA) and incubated with serum-free medium containing AlexaFluor-488-Tfn ( $25 \mu \mathrm{g} / \mathrm{ml}$, Molecular Probes, T13342) for the indicated times. Cells were then washed twice with ice-cold PBS, rinsed for 2 min with ice-cold sodium acetate buffer, $\mathrm{pH} 2.8(0.2 \mathrm{M}$ acetic acid/0.5 M $\mathrm{NaCl}, \mathrm{pH} 2.8$ ), and rinsed twice again with PBS. Cells were then trypsinized for $1 \mathrm{~min}$ at $37 \mathrm{C}$, harvested, washed twice in ice-cold PBS, and analyzed on a fluorescence-activated cell scanner (BD FACScan System, BD Biosciences). The mean fluorescence intensity was determined and plotted in function of time.

${ }^{125}$ I-EGF uptake. ${ }^{125}$ I-EGF uptake was performed as described previously (Sorkin and Duex, 2010). ${ }^{125}$ I-EGF was used at a final concentration of $2 \mathrm{ng} / \mathrm{ml}$.

EGFR endocytosis and degradation. Cell surface EGFR expression was determined by biotinylation and Western blotting using a sheep polyclonal anti-EGFR antibody (Fitzgerald). Briefly, exponentially growing SV40-transformed $S c y l 2^{+/+}$and $S c y l 2^{-/-}$MEFs (3 lines per genotype) in 6-well tissue culture plates were washed twice with PBS and incubated in serum-free medium for $2 \mathrm{~h}$ in the presence of cycloheximide $(25 \mu \mathrm{g} / \mathrm{ml})$. Cells were then stimulated with EGF $(10 \mathrm{ng} / \mathrm{ml})$ for the indicated times and washed three times with ice-cold PBS and incubated with $2 \mathrm{ml}$ of Sulfo-NHS-LC-Biotin $(0.25 \mathrm{mg} / \mathrm{ml}$, Pierce $)$ on ice for $30 \mathrm{~min}$. Cells were then incubated with an ice-cold glycine (10 mM in PBS) on ice. Cells were then washed 3 times with ice-cold PBS and lysed in $0.5 \mathrm{ml}$ RIPA buffer. Cell lysates were cleared by centrifugation, and $100 \mu \mathrm{g}$ of protein lysates was subjected to streptavidin affinity purification using ImmunoPure Immobilized Streptavidin (Pierce) for $2 \mathrm{~h}$ at $4^{\circ} \mathrm{C}$. Beads were washed three times with RIPA buffer, and samples were eluted in XT Sample Buffer (Bio-Rad, \#161-0791) containing 50 mm DTT. Biotinylated proteins were resolved by SDS-PAGE and analyzed by Western blotting. EGFR stability was determined by Western blotting using a sheep polyclonal anti-EGFR antibody (Fitzgerald).

For EGFR degradation studies, exponentially growing SV40-transformed Scyl2 $2^{+/+}$and Scyl2 $2^{-1-}$ MEFs (3 lines per genotype) in 6-well tissue culture plates were washed twice with PBS and incubated in serum-free medium for $2 \mathrm{~h}$ in the presence of cycloheximide $(25 \mu \mathrm{g} / \mathrm{ml})$. Cells were then stimulated with EGF $(100 \mathrm{ng} / \mathrm{ml})$ for the indicated times, washed three times with ice-cold PBS, and lysed in RIPA buffer. Protein extracts $(10 \mu \mathrm{g})$ were separated by SDS-PAGE and analyzed by Western blotting. Band intensities were quantified using National Institutes of Health ImageJ software version $1.42 \mathrm{q}$.

NR1 and NR2A endocytosis and degradation. Cell surface NR1 and NR2A expression was determined by biotinylation and Western blotting. Briefly, primary neuronal cultures obtained from Scyl2 ${ }^{+/+}(n=6)$ and Scyl2 ${ }^{-1-}(n=3)$ were cultured in 6-well tissue culture plates for $21 \mathrm{~d}$ in vitro. Cultures were washed twice with $\mathrm{PBS}$ and incubated HBSS supplemented with $\mathrm{CaCl}_{2}(1.26 \mathrm{~mm}), \mathrm{MgCl}_{2}(.49 \mathrm{~mm})$, and $\mathrm{MgSO}_{4}(.41 \mathrm{~mm})$ for $2 \mathrm{~h}$. At $30 \mathrm{~min}$ before stimulation, neurons were incubated in the presence of of cycloheximide $(25 \mu \mathrm{g} / \mathrm{ml})$. The cultures were then stimulated with glutamate $(200 \mu \mathrm{M})$ and glycine $(10 \mu \mathrm{M})$ for the indicated times. The cells were washed three times with ice-cold PBS and incubated with $2 \mathrm{ml}$ of Sulfo-NHS-LC-Biotin $(0.25 \mathrm{mg} / \mathrm{ml}$, Pierce $)$ on ice for $30 \mathrm{~min}$. Cells were then incubated with an ice-cold glycine (10 mm in PBS) on ice. Cells were then washed 3 times with ice-cold PBS and lysed in $0.5 \mathrm{ml}$ RIPA buffer. Cell lysates were cleared by centrifugation, and $50 \mu \mathrm{g}$ of protein lysates was subjected to streptavidin affinity purification using ImmunoPure Immobilized Streptavidin (Pierce) for $2 \mathrm{~h}$ at $4^{\circ} \mathrm{C}$. Beads were washed three times with RIPA buffer, and samples were eluted in XT Sample Buffer (Bio-
Rad, \#161-0791) containing 50 mm DTT. Biotinylated proteins were resolved by SDS-PAGE and analyzed by Western blotting.

Statistical analyses. The Mendelian ratio significance was determined by the $\chi^{2}$ test. The one-tailed or two-tailed Student's $t$ test was performed using Graph Pad Prism, version 6.02. $p$ values $\leq 0.05$ were considered statistically significant.

\section{Results}

\section{Ubiquitous and neuron-specific deletion of Scyl2}

To gain insights into SCYL2 function, mice bearing a conditional (Scyl2fl) or a null $(S c y l 2-)$ allele of Scyl2 were generated. A targeting construct was designed to insert loxP sites within introns 3 and 8 of Scyl2 (Fig. 1A; see Materials and Methods). The locations of loxP sites were chosen to ensure the generation of a null allele after Cre-mediated recombination. Southern blot (Fig. 1B), PCR (Fig. 1C), and Western blot analyses using antibodies against SCYL2 (Fig. 1D) confirmed the proper targeting of the gene and demonstrated the absence of SCYL2 in the brain of Scyl2-deficient mice, whereas the level of $\mathrm{CHC}$ was unchanged (Fig. 1D).

$S c y l 2^{+/-}, S c y l 2^{+/ f l}$, and $S c y l 2^{f l f l}$ mice were viable, fertile, and exhibited no overt abnormalities. Mating of $S c y l 2^{+/-}$mice yielded $S c y l 2^{+/+}, S c y l 2^{+/-}$, and $S c y l 2^{-/-}$mice according to normal Mendelian ratios at birth [postnatal day (P) 0.5, Table 1] but not at weaning (P21.5, Table 1), at which point only $3 \%$ (6 of 198) of the expected Scyl2 $2^{-/-}$mice were recovered. At birth, Scyl2deficient mice were indistinguishable from their wild-type $\left(S c y l 2^{+/+}\right)$or heterozygous $\left(S c y l 2^{+/-}\right)$littermates. Within hours, however, we noticed that $S c y l 2$-deficient mice failed to ingest milk (Fig. 1E), and the vast majority of them (97\%) died within $24 \mathrm{~h}$ after birth. Analysis of 31 mice found dead within $24 \mathrm{~h}$ after birth revealed that $>80 \%$ of them were Scyl2-deficient mice ( 25 of 31) (Table 2).

Feeding problems are often associated with neurological or craniofacial defects (Turgeon and Meloche, 2009). Histopathological examination of Scyl2-deficient newborn mice, however, failed to reveal any obvious craniofacial dysmorphogenesis, such as cleft palate in Scyl2-deficient mice (data not shown), suggesting that the perinatal lethality associated with the loss of SCYL2 may be of neurogenic origin. Consistent with a possible role for SCYL2 in regulating neuronal functions, we found that the small fraction of $S c y l 2$-deficient mice that survived to adulthood [3\% of all Scyl2-deficient mice generated; 3 males and 3 females (6 $S c y l 2^{-/-}$mice of 790 mice generated from a Scyl2 $2^{+/-}$intercross, Table 1)] exhibited growth retardation (Fig. $1 F$ ), sensory-motor deficits, and abnormal behaviors, such as limb clasping (Fig. $1 G$ ), a characteristic feature of many animal models of neurodegeneration (Côté et al., 1993; Mangiarini et al., 1996). Unfortunately, the limited number of mice that survived to adulthood prevented us from conducting an in-depth analysis of the phenotypes associated with the loss of Scyl 2 in adult mice.

To directly assess whether the perinatal lethality associated with the loss of $S c y l 2$ was of neurogenic origin, we sought to eliminate $S c y l 2$ specifically from the nervous system by crossing $S c y l 2^{f l f l}$ mice with mice expressing the Cre recombinase under the control of the rat nestin promoter (NesCre+ mice; see Materials and Methods). NesCre + mice express Cre recombinase specifically in neural progenitor cells by embryonic day 10.5 (Tronche et al., 1999). The absence of SCYL2 in the brain, but not in the liver, of NesCre $+; S c y l 2^{f l / f l}$ mice confirmed the neuralspecific recombination of the Scyl2 locus in these mice (Fig. 2A). Mating of NesCre $+; S c y l 2^{+/ f l}$ females with $S c y l 2^{f l f l}$ males yielded $S c y l 2^{+/ f l}, S c y l 2^{f l f l}, \mathrm{NesCre}+; S c y l 2^{+/ f l}$, and NesCre $+; S c y l 2^{f l / f l}$ mice according to normal Mendelian ratios at birth but not at weaning 


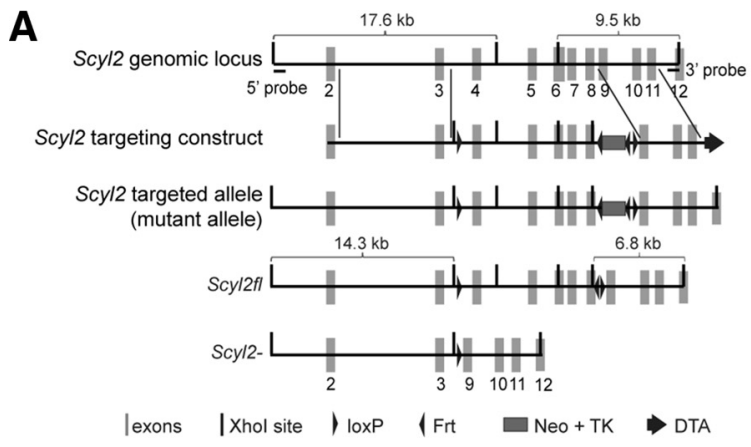

D

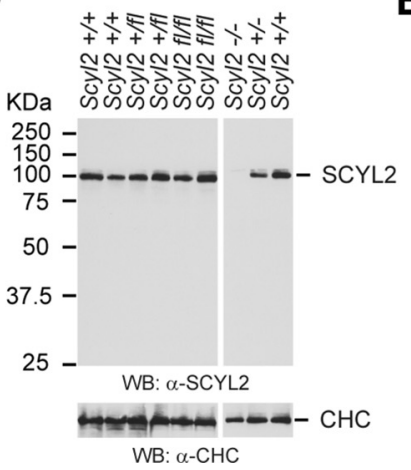

E

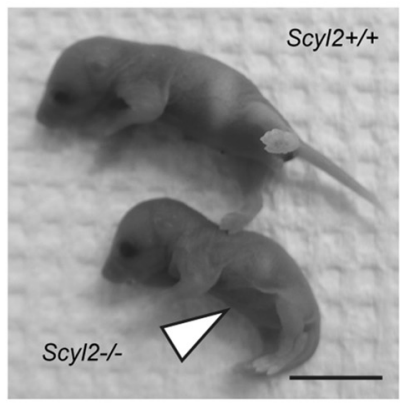

B

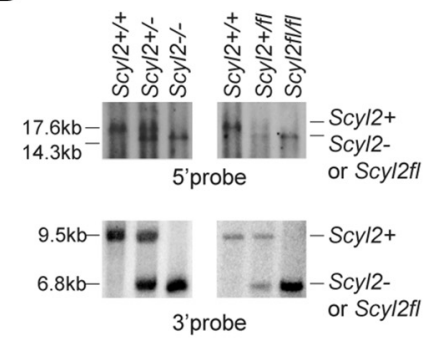

F

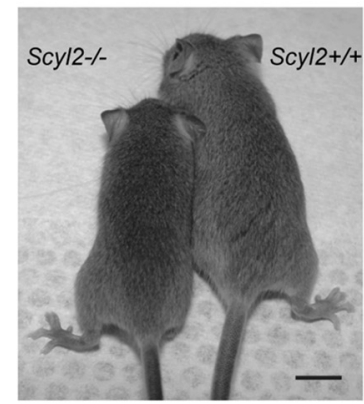

C

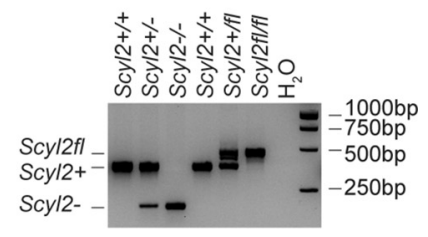

G

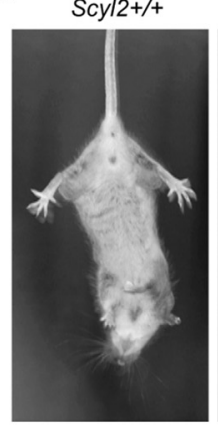

Scyl2-/-

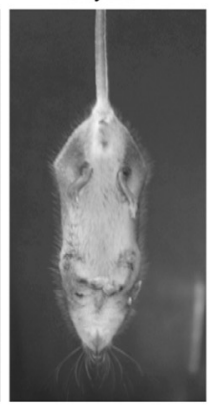

Figure 1. Targeted disruption of Scy/2 causes early lethality in the vast majority of newborn mice. $\boldsymbol{A}$, Schematic representation of the $S c y / 2$ locus, the targeting vector, and the Scyl2-mutated locus. The Scy/2 and Scy/2fI loci were generated after Cre- or FLP-mediated recombination in ES cells. Gray bars represent exons. Black bars represent EcoRI sites. Black triangles represent loxP and Frt sites. Gray box represents the Neo-TK cassette. The diphtheria toxin cassette is illustrated by a black arrow. B, Southern blot analysis of the Scyl2 genomic locus using $5^{\prime}$ and $3^{\prime}$ external probes on EcoRl-digested genomic DNA obtained from Scyl2 $2^{+/+}, \mathrm{Scyl} / 2^{+/-}, \mathrm{Scyl} / 2^{+/ f l}$, and Scy/2 ${ }^{\text {flfl }}$ mice. A band of $17.3 \mathrm{~kb}$ corresponding to the Scyl2+ allele and one of $14.3 \mathrm{~kb}$ corresponding to the null $(S c y / 2-)$ or conditional $(S c y / f l)$ are detected using the $5^{\prime}$ probe. Bands of $9.5 \mathrm{~kb}$ corresponding to the $S c y l 2+$ allele and $6.8 \mathrm{~kb}$ corresponding to the $S c y / 2-$ or $S c y / 2 f l$ allele are detected using the $3^{\prime}$ probe. C, PCR genotyping of the Scyl2 locus in Scy/2 ${ }^{+/+}, S c y / 2^{+/-}, S c y / 2^{+/ f l}$, and Scyl $2^{f / f l}$ mice. Bands of 354, 191, and 458 bp corresponding to the wild-type (WT) (Scyl2 +), null allele (Scyl2-), and conditional allele $(S c y / 2 f l)$, respectively, were obtained. D, SCYL2 expression in the cerebrum of Scyl2 ${ }^{+/+}$, Scyl2 ${ }^{+/ f l}, S c y / 2^{f / f l}, S c y / 2^{+/-}$, and Scyl2 ${ }^{-/-}$mice. Cerebrum extracts obtained from $\mathrm{Scyl} 2^{+/+}, \mathrm{Scyl} 2^{+/-}, \mathrm{Scyl} 2^{+/ f l}, \mathrm{Scyl} / 2^{f / f l}$, and Scyl2 $2^{-/-}$mice were resolved by SDS-PAGE and analyzed by Western blot, using antibodies against SCYL2 ( $\alpha$-SCYL2) and the CHC. Note the absence of

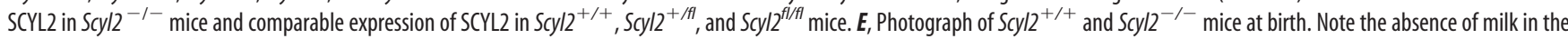

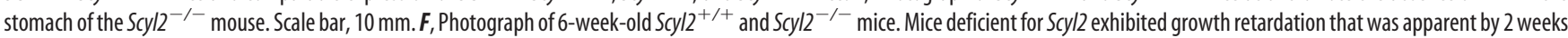
of age and remained throughout their lifetime. Scale bar, $10 \mathrm{~mm}$. G, Neurological reflexes in Scyl2 $2^{-/-}$mice. When suspended by their tails, Scyl2 ${ }^{+/+}$mice spread their hind limbs, whereas $\mathrm{Scyl} / 2^{-1-}$ mice grasped their hind limbs and forelimbs to their body.

\begin{tabular}{|c|c|c|c|}
\hline Postnatal day & Scyl2 $2^{+/+}[N(\%)]$ & Scyl2 $2^{+/-}[N(\%)]$ & Scyl/2-l- $[N(\%)]$ \\
\hline P0.5 & $39(25.3)$ & $79(51.3)$ & $36(23.4)$ \\
\hline P21.5/weaning & $270(34)$ & $514(65)$ & $6(0.8)$ \\
\hline
\end{tabular}

Table 2. Distribution of Scyl2 ${ }^{+/+}, \mathrm{Scyl} 2^{+/-}$, and Scyl2 ${ }^{-/-}$mice that died within $24 \mathrm{~h}$ after birth

\begin{tabular}{llll}
\hline Postnatal day & $S c y / 2^{+/+}[N(\%)]$ & $S c y / 2^{+/-}[N(\%)]$ & $S c y / 2^{-/-}[N(\%)]$ \\
\hline P0 & $2(6.4)$ & $4(12.9)$ & $25(80.6)$ \\
\hline
\end{tabular}

(Table 3). As seen with Scyl2-deficient mice, the majority of $\mathrm{Ne}$ sCre $+; S c y l 2^{f l / f l}$ mice ( $54 \%$ of them) appeared normal at birth but died within $24 \mathrm{~h}$ after birth due to malnutrition (Fig. 2B), suggesting that the perinatal lethality caused by the loss of $S c y l 2$ is of neurogenic origin. The partial penetrance of the phenotype in NesCre $+; S c y l 2^{\text {fl/fl }}$ mice is likely due to incomplete recombination events in some neurons, as shown previously for this Creexpressing mouse line (Pelletier et al., 2012), thus providing sufficient function to bypass lethality in some mice.

Similarly to Scyl2-deficient mice that survived to adulthood, the NesCre+; $S c y l 2^{f l f l}$ mice that that survived the perinatal lethality exhibited profound growth retardation (Fig. 2C; Table 4), abnormal reflexes (limb clasping; Fig. 2D), diminished grip strength (Fig. 2E), tremor, sensory motor deficits (data not shown), priapism (data not shown), and depression-like behavior (Fig. $2 \mathrm{~F}-H$ ). Growth retardation in NesCre $+; S c y l 2^{f l / f l}$ mice was readily detectable by 2 weeks of age and persisted throughout their lifetime. As seen in Scyl2-deficient mice, NesCre $+; S c y l 2^{f l f l}$ mice developed to only $50 \%-65 \%$ of the body weight of sex- and age-matched control littermates (Table 4). In the inverted cage grid test for assessing grip strength (Pelletier et al., 2012), NesCre $+; S c y l 2^{f l f l}$ mice held on to the inverted cage grid for a significantly ( $n=7$ mice, $p<0.01$ ) shorter period of time than did control mice (NesCre+;Scyl $2^{+/ f l}$ mice, $n=7$; Fig. $2 E$ ). Also, NesCre $+; S c y l 2^{f l f l}$ mice stayed stationary during the assay, whereas control littermates explored the cage grid and tried to escape. The tail suspension test to assess behavioral despair in neural-specific mutants revealed that latency to immobility, but not duration of immobility, in the last $4 \mathrm{~min}$ of the test was significantly lower in NesCre $+; S c y l 2^{f l / f l}$ mice than in control mice (Fig. 2F, G). The strength of movement also revealed that $\mathrm{Ne}$ sCre $+; S c y l 2^{f l f l}$ mice were less inclined to escape than control mice (Fig. $2 H$ ). Together, these results indicate that SCYL2 is dispensable for normal embryonic development but plays a critical role for the normal functioning of the nervous system. Importantly, the generation of a larger number of mice deficient for Scyl2 in the nervous system that survived to adulthood has provided critical insights into SCYL2 function, as detailed below. 


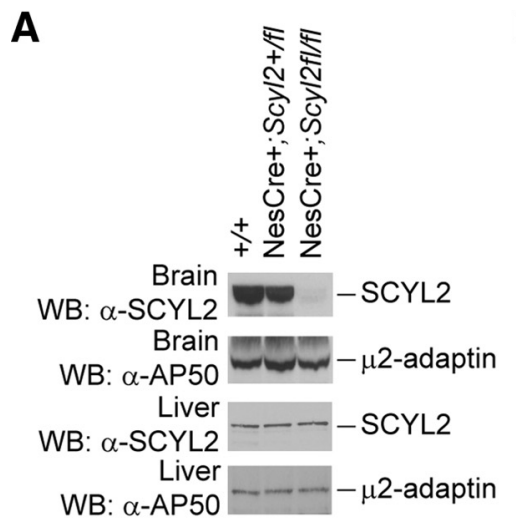

E

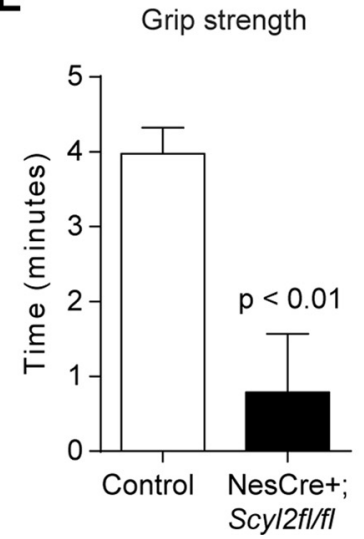

B

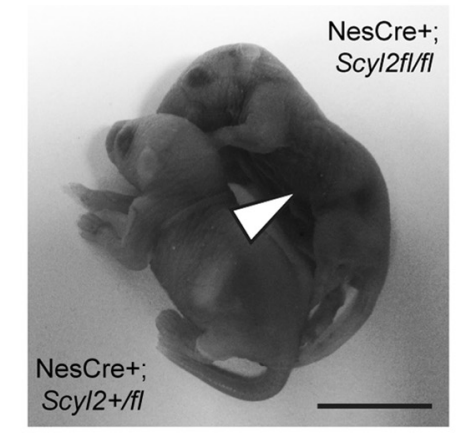

C

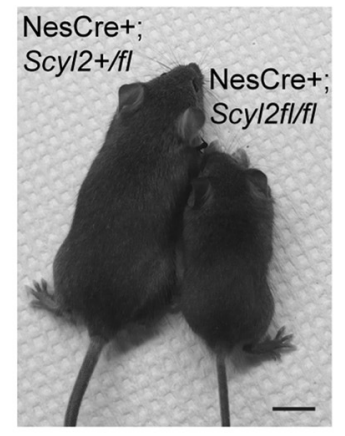

D

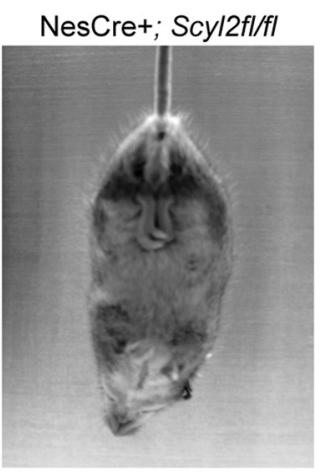

F

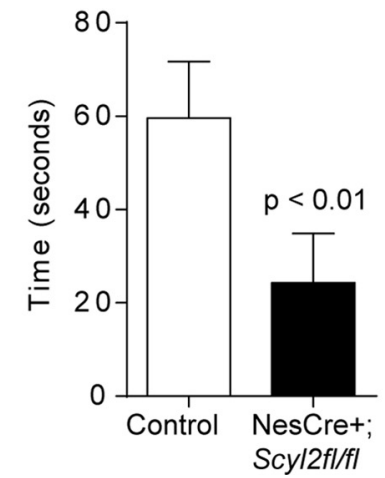

G
Duration

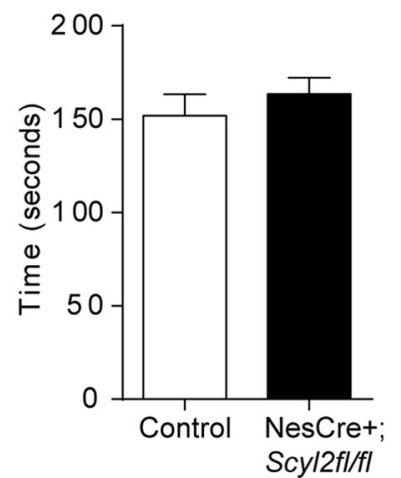

H

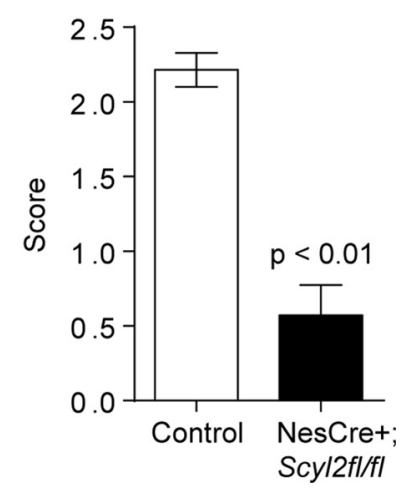

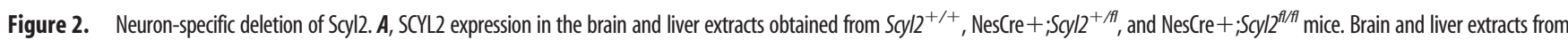

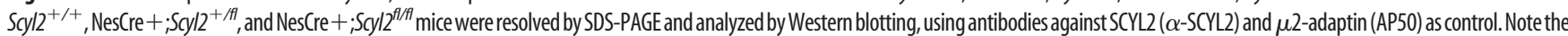

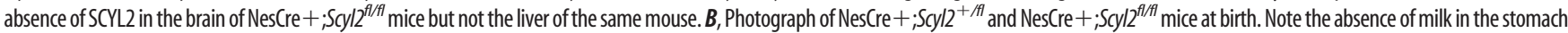

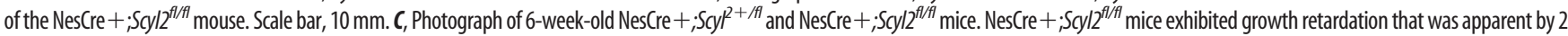
weeks of age and remained throughout their lifetime. Scale bar, $10 \mathrm{~mm}$. D, Abnormal reflexes of Nes(re $+; S c y / 2^{f / f / t}$ mice. When suspended by their tails, Nes(re $+;$ Scyl $/ 2^{+/ f /}$ mice spread their hind limbs, whereas

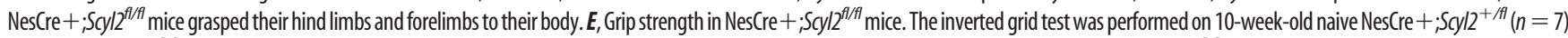
and NesCre $+; S c y \mid 2^{f / f}(n=7)$ males as described in Materials and Methods. Control mice held on significantly longer on the inverted grid than NesCre $+; S c y / 2^{f / f /}$ mice. Data are expressed as the mean \pm SEM. $p$ values, determined by the two-tailed Student's $t$ test, are indicated on the graph. During the tail suspension test, NesCre $+; S c y / 2^{+/ f t}$ mice explored the cage grid, but NesCre $+; S c y / 2^{f / f t}$ mice remained

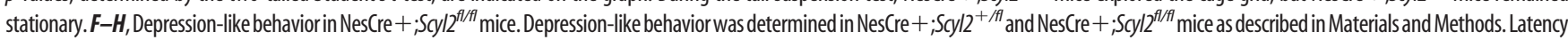
to immobility, a measure of depression-like behavior $(\boldsymbol{F})$, duration of immobility $(\boldsymbol{G})$, and strength of movement $(\boldsymbol{H})$ were determined in NesCre $+; S c y / 2^{+/ f f}(n=7)$ and Nes(re $+; S c y \mid 2^{f / f f}(n=7)$ animals. Data are mean \pm SEM. $p$ values, determined by the two-tailed Student's $t$ test, are shown on the graph.

Table 3. Distribution of $\mathrm{Scyl} 2^{+/ f l}, \mathrm{Scyl} / 2^{f / f t}, \mathrm{NesCre}+; \mathrm{Scyl} 2^{+/ f t}$, and NesCre $+; \mathrm{Scyl} 2^{f f f l}$ mice at weaning from a NesCre $+; \mathrm{Scyl}^{+/ f f l} \times \mathrm{Scy} / 2^{f / f t}$ cross

\begin{tabular}{|c|c|c|c|}
\hline $\begin{array}{l}\text { Scyl2 } \\
{[N(\%)]}\end{array}$ & $\begin{array}{l}S c y \mid 2^{f / f f} \\
{[N(\%)]}\end{array}$ & $\begin{array}{l}\text { NesCre+; ;cyl2 }{ }^{+/ f l} \\
{[N(\%)]}\end{array}$ & $\begin{array}{l}\text { NesCre+;Scyl| } 2^{f / / t} \\
{[N(\%)]}\end{array}$ \\
\hline 85 (29.4) & 88 (30.4) & $83(28.7)$ & 33 (11.4) \\
\hline
\end{tabular}

Absence of CA3 pyramidal neurons in NesCre $+; S c y l 2^{f l / f l}$ mice To gain insights into the neurological disorders associated with the loss of Scyl2 in neurons, MRI was performed on brains of $\mathrm{NesCre}+; S c y l 2^{+/ f l}$ and NesCre $+; S c y l 2^{f l f l}$ mice. Consistent with the growth abnormalities found in NesCre $+; S c y l 2^{f l / f l}$ mice, the brains of the mutant mice were smaller than those of control $\left(\mathrm{NesCre}+; S c y l 2^{+/ f l}\right.$ ) mice (Fig. $3 A$ ). We also noticed a dramatic reduction in the size of the hippocampi of NesCre $+; S c y l 2^{f l f l}$ mice compared with control animals (Fig. $3 A$, circle). The hippocampusto-brain height ratio in mutant mice was significantly smaller than that of control mice, whereas the brain height-to-width ratio was similar in mutant and control mice (Fig. $3 B$ ). These results were confirmed by staining of sagittal of brain sections with hematoxylin and eosin, revealing the near-complete absence of CA3 pyramidal neurons in NesCre $+; S c y l 2^{f l / f l}$ mice (Fig. $3 C$ ). We also observed di- minished cellularity in the DG but not in CA1 area of 20-week-old NesCre $+; S c y l 2^{f l f l}$ mice compared with control mice (data not shown). Of note, MRI and histological analyses also demonstrated the absence of CA3 neurons in Scyl2 ${ }^{-1-}$ mice (data not shown). Consistent with the absence of CA3 pyramidal neurons in NesCre+; $S c y l 2^{f l f l}$ mice, we found that synaptic transmission, recorded at excitatory synapses between the CA3 and CA1 pyramidal neurons (CA3-CA1 synapses), was severely impaired in NesCre+;Scyl ${ }^{f l f l}$ mice. Throughout stimulation intensities, field EPSPs in hippocampal slices from NesCre $+; S c y l 2^{f l / f l}$ mice were significantly lower $(p<$ $0.05, n=9$ slices from 3 NesCre $+; S c y l 2^{f l / f l}$ mice, $n=14$ slices from 3 NesCre $+; S c y l 2^{+/ f l}$ mice) than in those from control littermates (Fig. $3 D)$. The profound decrease in synaptic transmission in mutant mice is consistent with the notion that $S c y l 2$ deletion eliminated most CA3 neurons.

Loss of CA3 pyramidal neurons coincides with synaptogenesis of mossy fiber-CA3 synapses

At birth, brains of $S c y l 2^{-/-}$or NesCre+;Scyl $2^{f l f l}$ mice were indistinguishable from those of control littermates (data not shown), suggesting that the absence of CA3 neurons in Scyl2-deficient mice was the result of a degenerative process rather than a defect 
Table 4. Body weight (mean \pm SEM) of 5 -week-old Scyl2 ${ }^{+/+}, S c y / 2^{-/-}$, NesCre $+; S c y / 2^{+/ f t}$, and NesCre $+; S c y / 2^{f / f l}$ male and female mice

\begin{tabular}{|c|c|c|c|c|}
\hline Body weight (g) & Scyl2 $2^{+/+}$ & Scyl/2-1- & NesCre+;Scyl2 ${ }^{+/ f l}$ & NesCre+;Scyl $2^{f / f t}$ \\
\hline Males & $23.4 \pm 0.1(n=5)$ & $\begin{array}{l}12.0 \pm 1.0(n=3) \\
p<0.0001\end{array}$ & $19.7 \pm 0.4(n=6)$ & $\begin{array}{l}12.8 \pm 1.0(n=3) \\
p<0.0001\end{array}$ \\
\hline Females & $19.5 \pm 0.5(n=3)$ & $\begin{array}{l}11.7 \pm 0.3(n=3) \\
p=0.0002\end{array}$ & $15.9 \pm 0.3(n=3)$ & $\begin{array}{l}8.3 \pm 1.5(n=3) \\
p=0.0085\end{array}$ \\
\hline
\end{tabular}

A

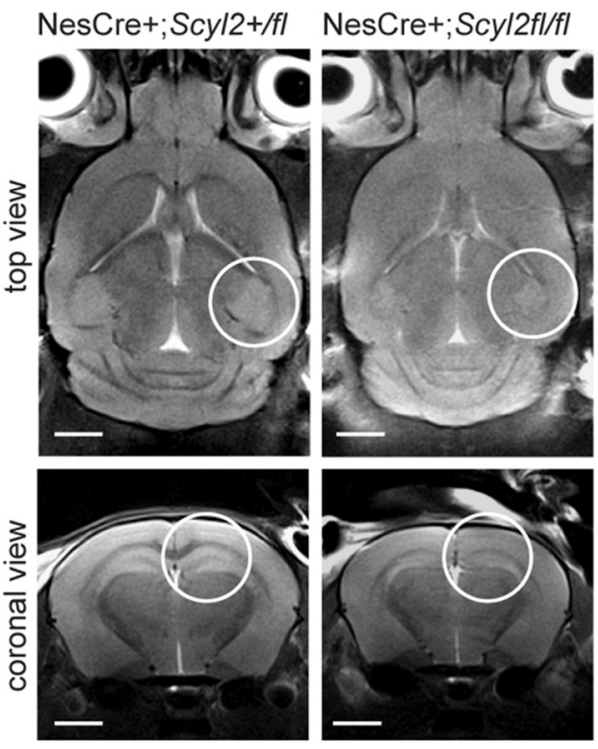

C

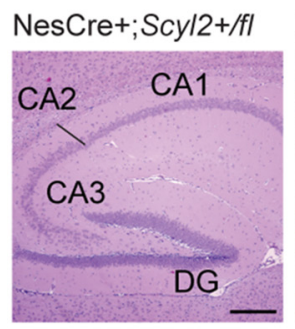

B

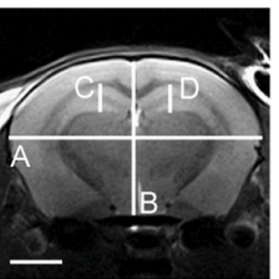

A: brain width

B: brain height

C: hippocampus (left)

D: hippocampus (right)
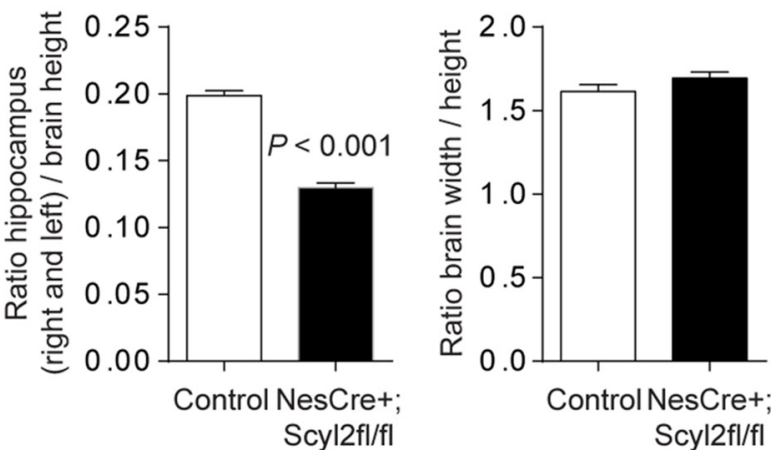

D

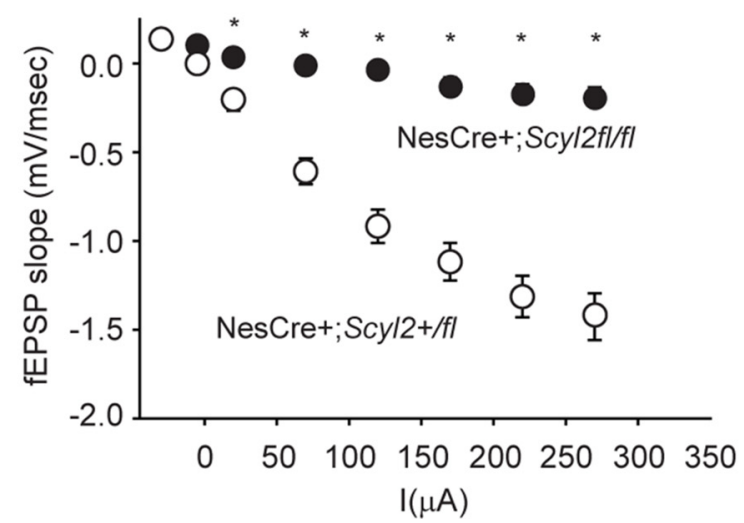

Figure 3. Absence of hippocampal CA3 pyramidal neurons in adult Scyl2-deficient mice. $A$, MRI revealed changes in the size of NesCre $+; S c y / 2 / f / f l$ mouse hippocampi. Top, View of NesCre + ; $\mathrm{Scyl} 2^{+/ f l}$ and NesCre $+; \mathrm{Scyl} 2^{f / f l}$ mouse brains. Brains of Nes(re $+; \mathrm{Scyl} / 2^{f / f f}$ were smaller than those of control mice, and a close examination of the hippocampal region (white circles) highlighted its reduced size compared with that of control mice. Scale bar, $2 \mathrm{~mm}$. B , The ratio of hippocampus height (segment C or D) to brain height (segment B) for control (NesCre $\left.+; S c y / 2{ }^{+/ f l}, n=3\right)$ and

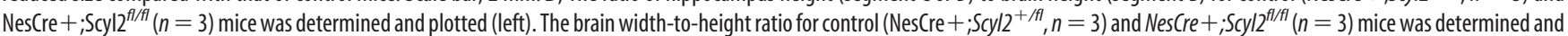
plotted (right). Values are mean \pm SEM. $p$ values, determined by the two-tailed Student's t test, are indicated on the graph. Scale bar, $2 \mathrm{~mm}$. C, The reduced size of hippocampal matter is associated with the absence of CA3 pyramidal neurons in NesCre $+; S C y / 2^{f / f t}$ mice. Hematoxylin and eosin-stained sections of hippocampi obtained from adult (20-week-old) Nestin-Cre $+; S c y / 2+/ f l a n d$ Nestin-Cre $+; S c y / 2^{f / f l}$ mice. Note the absence of CA3 pyramidal neurons in mutant mice (arrow). Scale bar, $250 \mu \mathrm{m}$. D. Mean fEPSP as a function of stimulated intensities in hippocampi obtained from 10-week-old NesCre $+; S c y / 2^{+/ f l}\left(n=3,14\right.$ slices) and NesCre $+; S c y \mid 2^{f / f l}\left(n=3,9\right.$ slices) mice. Values are mean \pm SEM. ${ }^{*} p<0.05$ (Student's $t$ test, Mann-Whitney).

in cell proliferation or migration, which occurs before birth (Mody et al., 2001). To determine the developmental stage at which degeneration occurred, we examined the architecture of the brain of P4.5, P6.5, P8.5, P14.5, and P2 1.5 control and mutant mice. At P4.5, hippocampi of NesCre $+; S c y l 2^{f l / f l}$ mice were indistinguishable from those of control littermates (Fig. 4A-D). At P6.5, although the cellularity in the CA3 area was similar in both control and mutant mice, the number of pyknotic cells was significantly higher in NesCre+;Scyl $2^{f l f l}$ mice (Fig. 4E). At P8.5, cellularity in the CA3 area in NesCre $+; S c y l 2^{f l / f l}$ mice was only
$20 \%$ of that in matched control littermates. The trend for substantial reduction of CA3 neurons was maintained to adulthood. By P14.5 and P21.5, there was also a significant reduction in DG cellularity in NesCre $+; S c y l 2^{f l / f l}$ mice compared with control mice (Fig. 4D), but there were no discernible changes in the CA1 area. The rapid and profound loss of CA3 neurons was also associated with neuroinflammation, as evidenced by the presence of activated glial cells in the CA3 area of the hippocampus of NesCre $+; S c y l 2^{f l f l}$ mice. The numbers of Iba1-positive cells (microglia) and of GFAP-positive cells (astrocytes) in the CA3 area of 
A
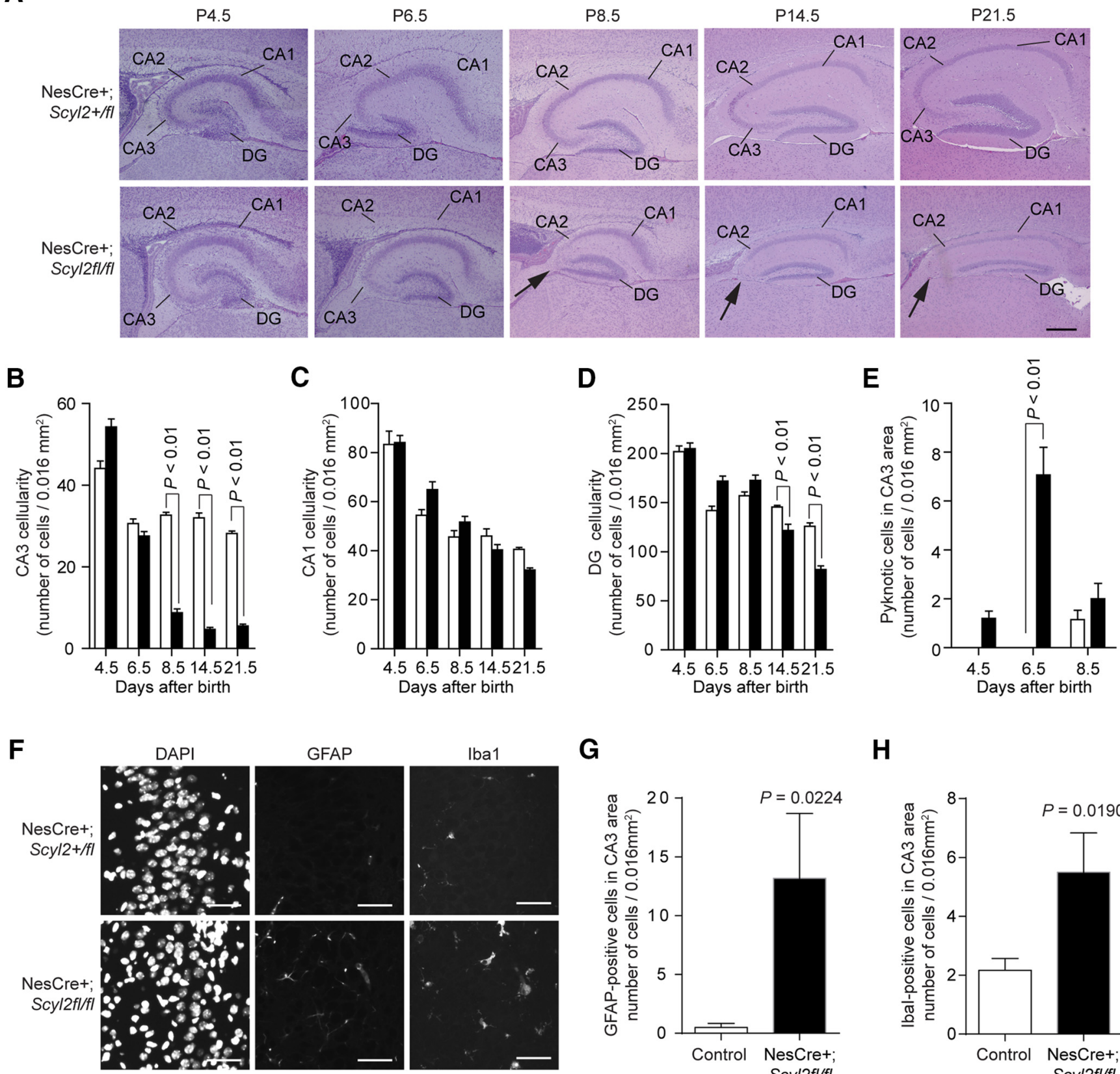

G

H
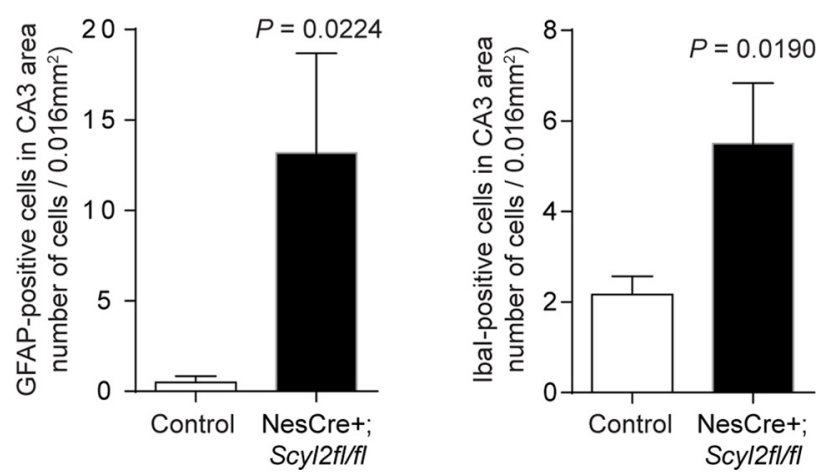

Figure 4. Loss of CA3 pyramidal neurons coincides with synaptogenesis and is associated with glial cell activation. $A$, Time course of CA3 pyramidal neuron degeneration in NesCre $+; S c y \mid 2^{f / f f l}$ mice. Micrograph of hematoxylin and eosin-stained sagittal sections of the hippocampus obtained from P4.5, P6.5, P8.5, P14.5, and P21.5 NesCre +; Scyl2 ${ }^{+/ f t}$ and NesCre $+; S c y \mid 2^{f / / f l}$ mice. Images are representative of observations from 3 mice per age group and genotype. Arrows point to the degenerating CA3 area of the hippocampus. CA1-3, CA1-3 fields of the hippocampus. Scale bar, 250 $\mu \mathrm{m} . \boldsymbol{B}-\boldsymbol{D}$, Cellularity in the CA3 (B), CA1 (C), and DG (D) area of the hippocampus of P4.5, P6.5, P8.5, P14.5, and P21.5 NesCre +; Scyl2 ${ }^{+/ f t}$ and NesCre $+;$ Scyl2 ${ }^{f / f t}$ mice. Cellularity was determined as described in Materials and Methods. E, Quantification of pyknotic cells in the CA3 area of hippocampi obtained from P4.5, P6.5, and P8.5 NesCre $+;$ Scyl2 ${ }^{+/ f t}$ and NesCre $+; S c y / 2^{f / f f}$ mice. The number of pyknotic cells in CA3 area was determined as described in Materials and Methods. $\boldsymbol{F}-\boldsymbol{H}$, Increased glial cell number and activation in the CA3 area of NesCre $+; S c y \mid 2^{f / f t}$ mice. Representative micrographs of immunofluorescence staining for GFAP and Iba1 in the CA3 area of NesCre $+; S c y / 2^{f / f t}$ mice $(\boldsymbol{F})$. The number of GFAP+ $(\boldsymbol{G})$ and Iba1 $+(\boldsymbol{H})$ cells in the CA3 area was determined as described in Materials and Methods. Scale bar, $50 \mu \mathrm{m}$. Values are mean \pm SEM of $6-15$ images from 3 mice per genotype and age group. $p$ values, determined by one-tailed $(\boldsymbol{F}, \boldsymbol{G})$ or two-tailed $(\boldsymbol{B}-\boldsymbol{E})$ Student's $t$ test, are indicated on the graph.

NesCre $+; S c y l^{f l / f l}$ mice were significantly higher than those in control mice (Fig. $4 F-H$ ). GFAP-positive cells were rarely seen in the pyramidal cell layer in control mice, whereas several GFAPpositive cells were present in NesCre+;Scyl2 $2^{f / f l}$ mice (Fig. 4F,G). Similarly, immunofluorescence staining for Ibal showed the fine cytoplasmic processes of normal microglial cells in control mice and an increase in the number of Ibal+ cells and in intensity of the staining in NesCre+;Scyl2 ${ }^{f / f l}$ mice (Fig. 4F,H). Together, the results indicate that neuron-specific deletion of $S c y l 2$ caused a rapid degenerative process that coincided with synaptogenesis in the developing hippocampus (Amaral and Dent, 1981; Mody et al., 2001).

Loss of CA3 neurons is the result of an apoptotic cell death The presence of pyknotic cells in the CA3 area of P6.5 NesCre+; $S c y l 2^{f l f l}$ mice suggested that apoptosis is involved in this degenerative process. Consistent with this, we observed an increased 
A

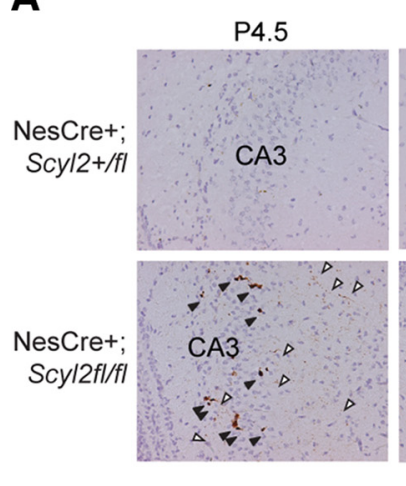

C

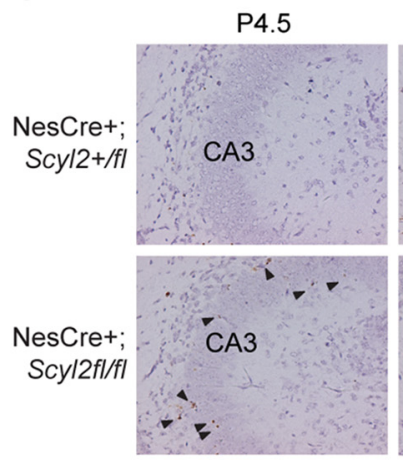

P6.5

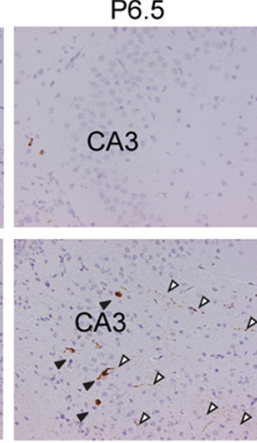

P6.5

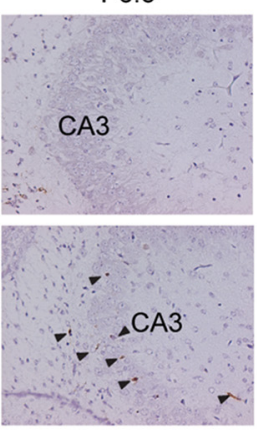

P8.5

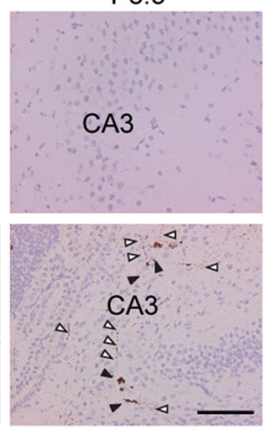

P8.5

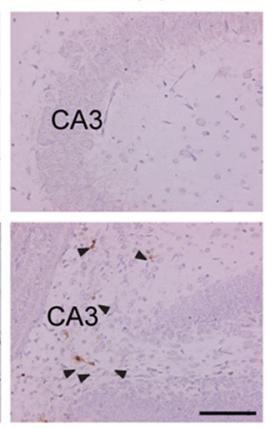

B

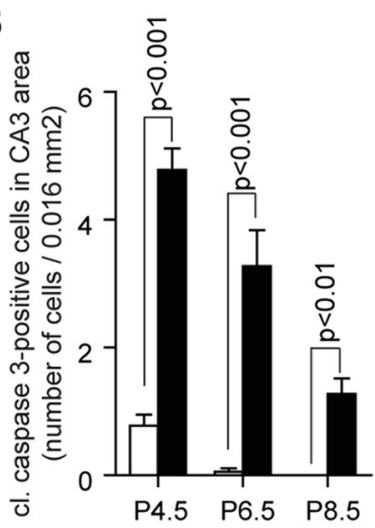

D

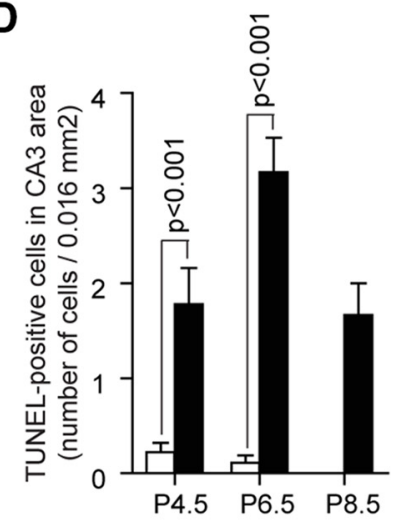

E

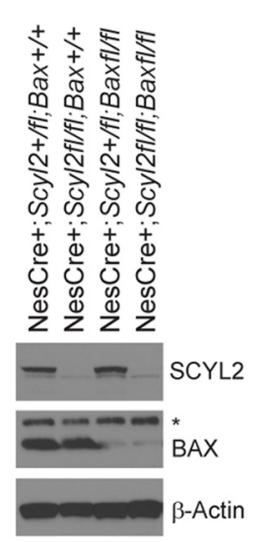

F

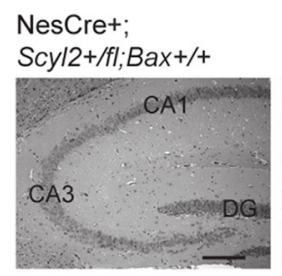

NesCre+;

Scyl2+/fl; Baxfl/fl

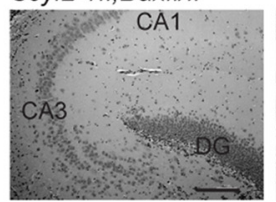

NesCre+; Scyl2fl/fl; $B \mathrm{Bax}+/+$

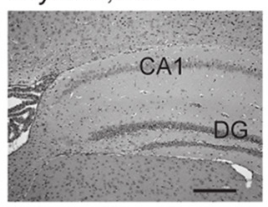

NesCre+;

Scyl2fl/fl;Baxfl/fl

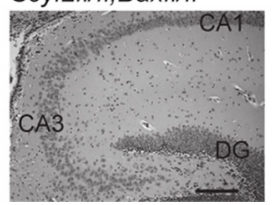

G

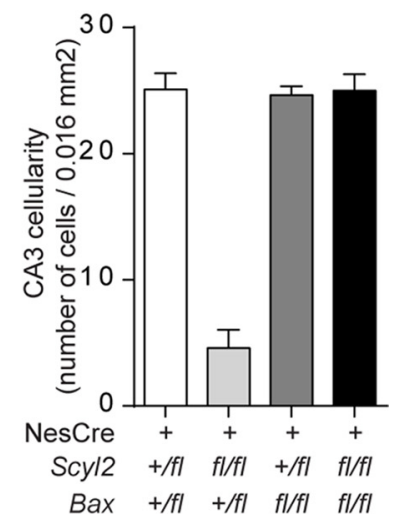

Figure 5. Loss of $C A 3$ neurons in $S c y / 2$-deficient mice is the result of apoptotic cell death. $A, B$, Caspase-3 activation in degenerating CA3 neurons. Immunohistochemical staining of brain sagittal sections obtained from postnatal day (P) 4.5, P6.5, and P8.5 NesCre $+; \mathrm{Scyl2}{ }^{+/ f t}$ and NesCre $+; S \mathrm{Cy} / 2^{f / / f}$ mice, using an anticleaved caspase-3 antibody. Black arrowheads indicate cleaved caspase3-positive cells. White arrowheads point to cleaved caspase-3-positive neuronal processes. $\boldsymbol{B}$, The histogram represents the quantification of cleaved caspase-3-positive cells in the CA3 area of hippocampi obtained from P4.5, P6.5, and P8.5 NesCre $+; \mathrm{SCy} / 2^{+/ f f}$ and NesCre $+; S C y / 2^{f / f f}$ mice. Values are mean \pm SEM of 15 images from 3 different mice per genotype and age group. $p$ values, determined by the two-tailed Student's t test, are indicated on the graph. Scale bar, $100 \mu \mathrm{m}$. C, D, CA3 degenerating neurons are positive for TUNEL staining. TUNEL staining of brain sagittal sections obtained from P4.5, P6.5, and P8.5 NesCre+;Scyl2 ${ }^{+/ f l}$ and NesCre +;Scyl2 ${ }^{f / f f}$ mice. D, Graph represents the quantification of TUNEL-positive cells in the CA3 area of hippocampi obtained from P4.5, $\mathrm{P} 6.5$, and P8.5 NesCre $+; \mathrm{Scy} / 2^{+/ f f}$ and NesCre $+; \mathrm{Scy} / 2^{f / f f}$ mice. Arrows point to TUNEL-positive cells within the CA3 area. Values are mean \pm SEM of 15 images from 3 different mice per genotype and age group. $p$ values, determined by the two-tailed Student's $\mathrm{t}$ test, are indicated on the graph. Scale bar, $100 \mu \mathrm{m}$. $\boldsymbol{E}$, Generation of NesCre $+; S \mathrm{Cy} / 2^{f / f f} ; B a x^{f / f / t}$ mice. Western blot analysis of brain

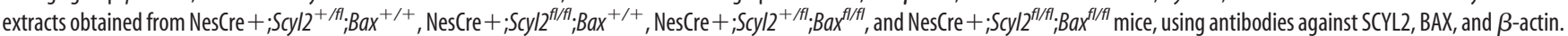

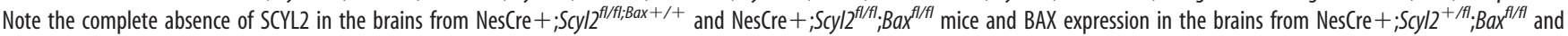

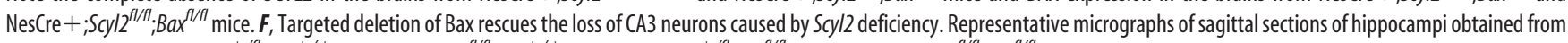

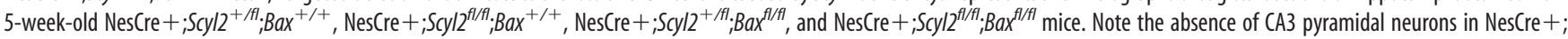

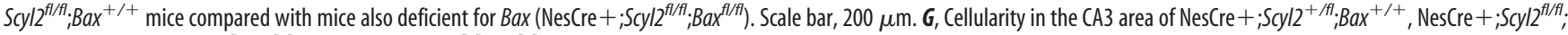

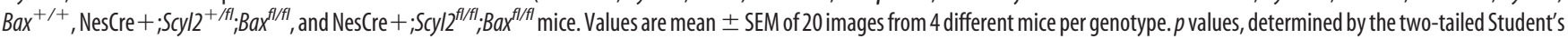
$t$ test, are indicated on the graph.

number of cleaved caspase 3-positive cells (Fig. 5A,B) and TUNEL-positive (Fig. 5C,D) cells in CA3 area of P4.5, P6.5, and P8.5 NesCre $+; S c y l 2^{f l f l}$ mice compared with NesCre $+; S c y l 2^{+/ f l}$ mice. TUNEL-positive and cleaved caspase 3-positive cells were also observed in the granular layer of the cerebellum of P6.5 NesCre $+; S c y l 2^{f l f l}$ mice (data not shown), indicating that, in addition to the hippocampus, other regions of the brain were also affected by the loss of Scyl2. 


\begin{tabular}{|c|c|c|c|c|c|c|c|c|}
\hline \multicolumn{9}{|c|}{ Genotypes } \\
\hline NesCre & - & - & - & - & + & + & + & + \\
\hline Scyl2 & $+/ f l$ & $f \mid / f l$ & $+/ f l$ & $f l / f l$ & $+/ f l$ & $f l / f l$ & $+/ f l$ & $f l / f l$ \\
\hline Bax & $+/ f l$ & $+/ f l$ & $f / f l$ & $f / f l$ & $+/ f l$ & $+/ f l$ & $f / f l$ & $f / f l$ \\
\hline$N(\%)$ & $55(16.1)$ & $43(12.6)$ & 65 (19.1) & $45(13.2)$ & $58(17.0)$ & $13(3.8)$ & $53(15.5)$ & $9(2.6$ \\
\hline
\end{tabular}

A

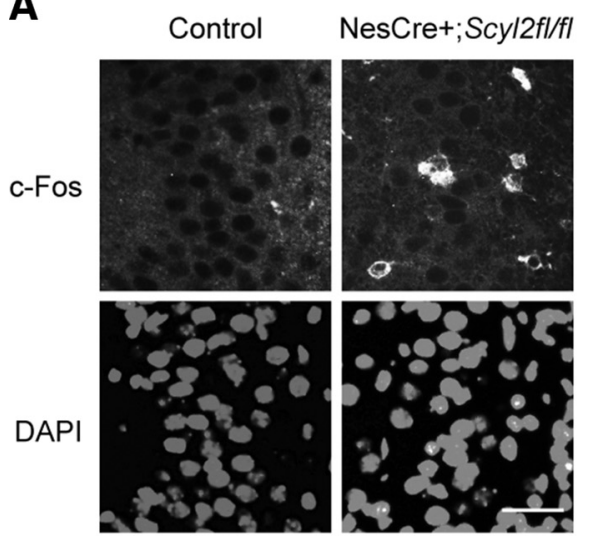

B

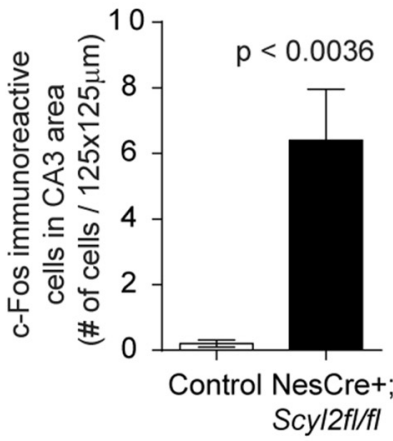

C

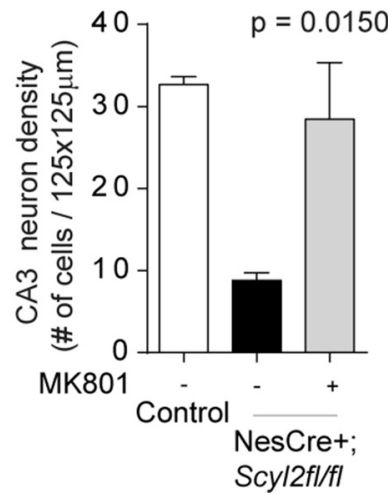

Figure 6. Loss of CA3 neurons is the result of excitotoxicity. $A$, Representative micrographs of immunofluorescence staining of brain sagittal sections obtained from P6.5 NesCre $+; S c y / 2^{+/ f t}$ and NesCre $+; S C y / 2^{f / f f l}$ mice, using the anti-c-Fos antibody. Scale bar, $50 \mu \mathrm{m}$. B, Histogram of c-Fos-immunoreactive cells in the CA3 area of hippocampi obtained from P6.5 NesCre $+;\left.S C y\right|^{2+/ f t}$ and $\mathrm{Nes}\left(\mathrm{Ce}+; \mathrm{SCy} / 2^{f / f t}\right.$ mice. Values are mean \pm SEM of 6 images from 4 different mice per genotype and age group. $p$ values, determined by the two-tailed Student's $t$ test, are indicated on the graph. C, Intraperitoneal administration of MK-801 (0.3 mg/kg/d) prevented the loss of CA3 neurons in NesCre+;Scyl/f//ft mice. P2.5 pups were administered MK801 at a dose of $0.3 \mathrm{mg} / \mathrm{kg} / \mathrm{d}$ for 6 consecutive days. At P8.5, mice were killed and brains were fixed and analyzed by hematoxylin and eosin staining. CA3 field cellularity was determined as described in Materials and Methods. Values are mean \pm SEM of 5 images from 4 mice per genotype. $p$ values, determined by the two-tailed Student's $t$ test, are indicated on the graph.

To directly determine whether apoptosis was involved in the degeneration of CA3 neurons, NesCre $+; S c y l 2^{f l f l}$ mice were crossed with mice bearing conditional alleles of $\operatorname{Bax}\left(B a x^{f l / f l}\right)$, a key mediator of the mitochondrial pathway of apoptosis (Tait and Green, 2010). Western blot analyses using antibodies to BAX or SCYL2 confirmed the proper rearrangement of these loci in the brains of these mice (Fig. $5 E$ ). As seen with NesCre $+; S c y l 2^{f l f l}$ mice, NesCre $+; S c y l 2^{f l / f l} ; B a x^{f l / f l}$ mice were not obtained according to the normal Mendelian ratio at weaning and were smaller than their control littermates (Table 5; data not shown). Interestingly, limb clasping was no longer apparent in NesCre $+; S c y l 2^{f l / f l} ; B a x^{f l / f l}$ mice (data not shown), suggesting that this behavior resulted from a neurodegenerative process. Strikingly, histopathologic analyses revealed no overt abnormalities in the brain of $\mathrm{Ne}$ sCre $+; S c y l 2^{f l / f l} ; B a x^{f l / f l}$ mice, indicating that BAX deficiency in the brain completely rescued the loss CA3 pyramidal neurons seen in NesCre+;Scyl ${ }^{f l / f l}$ mice (Fig. $5 F, G$ ). Together, these results indicate that the loss of CA3 pyramidal neurons in NesCre $+; S c y l 2^{f l / f l}$ mice is the result of a BAX-dependent apoptotic process.

\section{SCYL2 is a suppressor of excitotoxicity}

Because CA3 pyramidal neurons are particularly sensitive to excitotoxicity, an apoptotic cell death caused by excessive excitatory signaling (Nadler et al., 1978; Leist and Nicotera, 1998; Hara and Snyder, 2007), we next sought to determine whether excessive excitatory signaling occurred in CA3 pyramidal neurons of NesCre $+; S c y l 2^{f l f l}$ mice and whether blocking excitatory signaling could prevent the loss of CA3 pyramidal neurons in the developing brain of NesCre $+; S c y l 2^{f l / f l}$ mice. To determine whether excessive excitatory signaling occurred in CA3 pyramidal neurons of NesCre $+; S c y l 2^{f l / f l}$ mice, we monitored c-Fos expression, a biomarker of neuronal activity and excitotoxicity (Smeyne et al., 1993; Rogers et al., 2004, 2005), in the CA3 area of control and NesCre $+; S c y l 2^{f l / f l}$ mice at onset of the neurodegenerative process. As shown in Figure $6 A, B$, the number of c-Fosimmunoreactive CA3 neurons was significantly higher $(p<$ $0.01)$ in NesCre $+; S c y l 2^{f l f l}$ mice than in control mice, suggesting that excessive excitatory signaling indeed occurred in CA3 pyramidal neurons of NesCre $+; S c y l 2^{f l f l}$ mice. We next sought to reduce excitatory signaling in the developing brain of NesCre+; $S c y l 2^{f l f l}$ mice by blocking NMDA receptors, which are known key mediators of excitotoxicity during hypoxia ischemia, hypoglycemia, sustained seizures, and chronic neurodegenerative diseases (Hara and Snyder, 2007). Successive administration of MK-801, an irreversible NMDA receptor antagonist, from P2.5 to P8.5 prevented the loss of CA3 pyramidal neurons in vivo (Fig. 6C), indicating that loss of CA3 neurons in NesCre $+; S c y l 2^{f l / f l}$ mice was the result of excitotoxicity.

\section{Altered expression of excitatory receptors at synapses in Scyl2-deficient mice}

Because the loss of CA3 neurons in Scyl2-deficient mice was the result of aberrant excitatory signaling, we hypothesized that excitatory receptor expression at synapses may be altered in the brain of NesCre $+; S c y l 2^{f l f l}$ mice. To test this, we measured the expression of NR1 subunit of the NMDA receptor and the KA1 subunit of the kainic acid receptor, two glutamate receptor subunits known to mediate excitotoxicity in the CA3 area of the hippocampus (Nadler et al., 1978; Leist and Nicotera, 1998; Hara and Snyder, 2007). The ratio of protein expression in the synaptosomal membranes (LP1 fraction) to total expression (homogenate, $\mathrm{H}$ ) was determined in the P5.5 mouse brains before the 
A

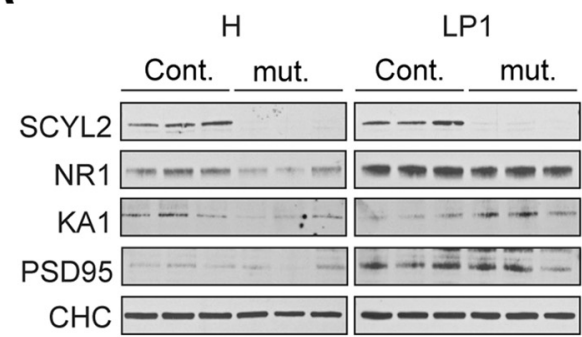

B
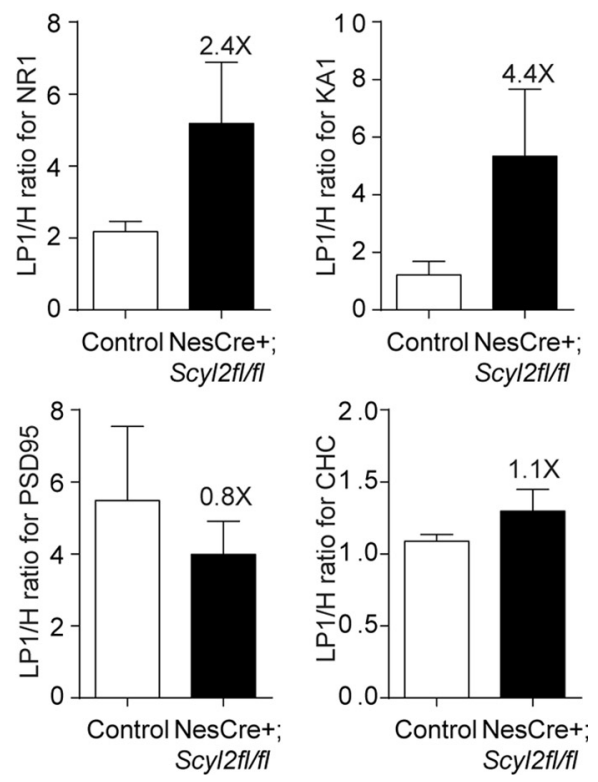

Figure 7. Increased synaptic expression of NR1 and KA1 receptors in the brain of NesCre + ; $\mathrm{Scy} / 2^{f / / f l}$ mice. $\boldsymbol{A}$, Increased excitatory receptor expression in synaptosomal membranes of $\mathrm{NeSCre}+; \mathrm{Scyl} 2^{f / f f l}$ mice. Western blot analysis of synaptosomal fractions obtained from 3 (NesCre $+; S c y / 2^{+/ f l}$ or NesCre $\left.+; S c y / 2^{+/+}\right)$and 3 NesCre $+; S c y / 2^{f / / f l}$ mouse brains, using antibodies against SCYL2, NR1, KA1, PSD95, and CHC. $\boldsymbol{B}$, Quantification of Western blots illustrated in $\boldsymbol{A}$. $\mathrm{LP} 1 / \mathrm{H}$ ratios were determined from 4 control and $3 \mathrm{NesCre}+; \mathrm{Scyl} 2^{f / f l}$ mice as detailed in Materials and Methods, and Values are mean \pm SEM.

degeneration of CA3 neurons. The LP1/H ratio for the NR1 subunit increased by 2.4-fold in NesCre+;Scyl $2^{f l f l}$ mice compared with control mice (Fig. $7 A, B$ ). Similarly, the relative expression of the KA1 subunit was increased by 4.4 -fold compared with control mice (Fig. $7 A, B$ ). In contrast, the expression of $\mathrm{CHC}$ and PSD-95 did not substantially change. The enrichment of synaptosomal membranes was confirmed by the $\mathrm{LP} 1 / \mathrm{H}$ ratios for PSD95, which were $\sim 5$-fold in control and NesCre+;Scyl $2^{f l / f l}$ mice (Fig. $7 A, B$ ). These results indicate that $S c y l 2$-deficient synapses express higher levels of NR1 and KA1 receptors than do control synapses. Given the role of NMDA receptors and KARs in mediating CA3 neurotoxicity, we propose that increased expression of these receptors contributes to the neurotoxicity seen in NesCre $+; S c y l 2^{f l f l}$ mice.

\section{Discussion}

In this study, we demonstrate that SCYL2 is essential for the normal functioning of the nervous system and for suppressing excitatory signaling and excitotoxicity during the functional maturation of the hippocampus. We also provide evidence that aberrant expression of excitatory receptors (i.e., NR1 and KA1) may account for the neurodegenerative phenotype seen in Scyl2deficient mice.
Excitotoxicity is an apoptotic cell death triggered by excessive activation of calcium-permeable glutamate receptors. It plays a central role in the pathogenesis of neurodegenerative disorders and underlies most of the neuronal damages after stroke or traumatic brain injuries (Gieselmann et al., 1984; Choi, 1988; Olney, 1989, 1993). Hyperactivation of calcium-permeable glutamate receptors causes calcium overload within neurons, activation of proapoptotic proteins, and neuronal demise (Gillessen et al., 2002; Hara and Snyder, 2007). A hallmark of excitotoxicity is cellular selectivity. CA3 pyramidal neurons, for example, are particularly sensitive to sustained limbic seizures, global ischemia, and the administration of neurotoxins, such as kainate (Choi, 1988; Olney, 1989). The increased sensitivity of CA3 neurons to cytotoxic insults has been attributed to the high expression of synaptic kainic acid receptors, which promote glutamate release and sodium influx, leading to membrane depolarization and activation of NMDA receptors (Choi, 1988).

The role of SCYL2 as a suppressor of excitotoxicity is supported by several observations: (1) loss of CA3 neurons occurred between P4.5 and P8.5, a period that is concomitant to mossy fiber-CA3 synapse formation (Amaral and Dent, 1981); (2) the degeneration process exhibited hallmarks of apoptosis (e.g., caspase- 3 activation, DNA fragmentation, pyknosis, and glial cell activation) (Leist and Nicotera, 1998; Hara and Snyder, 2007); (3) loss of CA3 neurons was reversed by ablation of the proapoptotic protein BAX, a well-characterized mediator of the mitochondrial pathway of apoptosis and excitotoxicity (Xiang et al., 1998; Tait and Green, 2010); (4) expression of c-Fos, a marker of excitotoxic cell death (Smeyne et al., 1993; Rogers et al., 2004, 2005), was highly induced in CA3 neurons before cell death; and (5) MK-801, an NMDA receptor antagonist, prevented the loss of CA3 neurons in vivo. Mechanistically, we found that Scyl2deficient mice expressed aberrantly high levels of kainic acid and NMDA receptors at synapses.

The relationship between SCYL2 and the aberrant expression of excitatory neurotransmitter receptors in Scyl2-deficient mice, however, is still unclear. Initially identified through subcellular proteomics as a clathrin vesicle-associated protein kinase (Wasiak et al., 2002), SCYL2 was subsequently proposed to regulate essential cellular functions, such as clathrin-mediated endocytosis (Conner and Schmid, 2005) and sorting at the trans-Golgi network (Düwel and Ungewickell, 2006; Borner et al., 2007). Consistent with a prominent role for SCYL2 in regulating clathrin-mediated functions in vivo, previous studies using morpholino-mediated gene knockdown have demonstrated that SCYL2 and core components of the clathrin machinery (e.g., AP1 and AP2) are required for normal morphogenesis in Xenopus tropicalis, and the similarities between the phenotypes associated with SCYL2 and AP1 knockdowns supported the idea that SCYL2 and AP1 may function in the same pathway (Borner et al., 2007). Unexpectedly, we found that, unlike targeted disruptions of core components of the clathrin machinery in mice (Meyer et al., 2000; Mitsunari et al., 2005; Lee et al., 2008; Chen et al., 2009; Ferguson et al., 2009) and inactivation of clathrin in flies or planarians which cause early embryonic lethality (Bazinet et al., 1993; Inoue et al., 2007), targeted deletion of Scyl2 in mice had milder consequences suggesting that SCYL2 plays at most an accessory role in regulating clathrin functions. The presence of severe morphological abnormalities in Xenopus embryos following SCYL2 depletion, but not in Scyl2-deficient mice, suggests that SCYL2 may have evolved to perform more specific functions in mammals. However, in light of recent findings, in which a comparison of published morphant (morpholino-induced) pheno- 
types with the Sanger Zebrafish Mutation Project reveal that $\sim 80 \%$ of morphant phenotypes are not observed in genetically engineered mutants and are likely due to off-target effects (Kok et al., 2015), it is conceivable that the defects in X. tropicalis development following SCYL2 depletion may have been the result off-target activity (Eisen and Smith, 2008; Kok et al., 2015; Schulte-Merker and Stainier, 2014).

By using proteomics and biochemical and cell-biological approaches, we confirmed that SCYL2 can interact and colocalize with core components of the clathrin machinery in both MEFs and primary neuronal cultures (data not shown; for experimental details, see Materials and Methods). However, unlike previously published data about clathrin, AP1, AP2, or AP3 (Meyer et al., 2000; Peden et al., 2002; Motley et al., 2003), we found that a wide variety of clathrin/AP-mediated functions were preserved in Scyl2-deficient MEFs. Transferrin and EGF endocytosis, EGFR internalization, as well as sorting of several lysosomal enzymes ( $\beta$-galactosidase, $\beta$-hexosaminidase, $\beta$-mannosidase, $\beta$-glucuronidase, and acid phosphatase), LAMP-1, MPR46, and MPR300 proceeded normally in Scyl2-deficient MEFs, whereas these functions are drastically impaired in clathrin-, AP1-, AP2-, or AP3-depleted cells (Meyer et al., 2000; Peden et al., 2002; Motley et al., 2003). Similarly, expression and steady-state distribution of clathrin, AP1, AP2, AP3, Vti1b, MPR46, MPR300, and LAMP-1 were essentially identical in Scyl2 ${ }^{+/+}$and Scyl2 ${ }^{-/-}$MEFs (data not shown; for experimental details, see Materials and Methods).

Previous studies also suggested a role for SCYL2 in regulating cell surface receptor expression by inducing lysosomal degradation (Terabayashi et al., 2009). Interestingly, targeted inactivation of Stam1 or the neuron-specific inactivation of Hrs also causes severe neurological disorders associated with the progressive loss of CA3 neurons (Yamada et al., 2001; Tamai et al., 2008). In Stam1-deficient mice, loss of CA3 neurons is associated with an increased susceptibility to glutamate-induced neurotoxicity (Yamada et al., 2001). Together with HRS, STAM1 or STAM2 form the ESCRT-0 complex. ESCRT-0 is involved in the initiation step of the multivesicular body pathway that forms at the early endosome and delivers ubiquitinated membrane proteins and lipids to the lysosomes for degradation (Schmidt and Teis, 2012). The similarities between phenotypes associated with the loss of Scyl2, Stam1, or Hrs suggest that SCYL2 and the ESCRT-0 complex function in the same pathway. However, unlike HRS and STAM proteins, which contribute to the targeting of EGFR for lysosomal degradation (Kanazawa et al., 2003), EGFR turnover proceeded normally in Scyl2-deficient MEFs (data not shown; for experimental details, see Materials and Methods). Similarly, NR1 or NR2A receptor internalization and degradation in response to glutamate/glycine stimulation proceeded normally in Scyl2-deficient hippocampal neurons (data not shown). Moreover, unlike previously reported data about SCYL2 (Terabayashi et al., 2009), we found no significant differences in Fzd5 expression between in Scyl2 $2^{+/+}$and Scyl2 $2^{-/-}$MEFs (data not shown). Together, our results suggest that SCYL2 functions independently of clathrin and degradative lysosomal pathways to regulate excitatory receptor expression and signaling. SCYL2 may function by limiting delivery of receptors to synapses. However, we have not been able to identify the exact transport step regulated by SCYL2 in neurons, assuming that transport is actually at fault here. Our current hypotheses also include a role for SCYL2 in regulating protein quality control along the biosynthetic pathway, similar to what we have proposed for SCYL1 at the ER-Golgi intermediate compartment (Pelletier et al., 2012).
Our results, together with previous findings demonstrating the role of SCYL1 in preventing motor neuron degeneration in mice (Pelletier et al., 2012), clearly establish the SCY1-like family of protein pseudokinases as key regulators of neuronal function and survival. Additional studies, however, will be required to better define the role of SCYL2 in regulating excitatory signaling and its relationship with the clathrin machinery.

\section{References}

Amaral DG, Dent JA (1981) Development of the mossy fibers of the dentate gyrus: I. A light and electron microscopic study of the mossy fibers and their expansions. J Comp Neurol 195:51-86. CrossRef Medline

Bayazitov IT, Richardson RJ, Fricke RG, Zakharenko SS (2007) Slow presynaptic and fast postsynaptic components of compound long-term potentiation. J Neurosci 27:11510-11521. CrossRef Medline

Bazinet C, Katzen AL, Morgan M, Mahowald AP, Lemmon SK (1993) The Drosophila clathrin heavy chain gene: clathrin function is essential in a multicellular organism. Genetics 134:1119-1134. Medline

Beaudoin GM 3rd, Lee SH, Singh D, Yuan Y, Ng YG, Reichardt LF, Arikkath J (2012) Culturing pyramidal neurons from the early postnatal mouse hippocampus and cortex. Nat Protoc 7:1741-1754. CrossRef Medline

Borner GH, Rana AA, Forster R, Harbour M, Smith JC, Robinson MS (2007) CVAK104 is a novel regulator of clathrin-mediated SNARE sorting. Traffic 8:893-903. CrossRef Medline

Burman JL, Bourbonniere L, Philie J, Stroh T, Dejgaard SY, Presley JF, McPherson PS (2008) Scyll, mutated in a recessive form of spinocerebellar neurodegeneration, regulates COPI-mediated retrograde traffic. J Biol Chem 283:22774-22786. CrossRef Medline

Burman JL, Hamlin JN, McPherson PS (2010) Scyll regulates Golgi morphology. PLoS One 5:e9537. CrossRef Medline

Castagne V, Moser P, Roux S, Porsolt RD (2011) Rodent models of depression: forced swim and tail suspension behavioral despair tests in rats and mice. Curr Protoc Neurosci Chapter 8:Unit 8 10A.

Chen H, Ko G, Zatti A, Di Giacomo G, Liu L, Raiteri E, Perucco E, Collesi C, Min W, Zeiss C, De Camilli P, Cremona O (2009) Embryonic arrest at midgestation and disruption of Notch signaling produced by the absence of both epsin 1 and epsin 2 in mice. Proc Natl Acad Sci U S A 106:1383813843. CrossRef Medline

Choi DW (1988) Glutamate neurotoxicity and diseases of the nervous system. Neuron 1:623-634. CrossRef Medline

Conner SD, Schmid SL (2005) CVAK104 is a novel poly-L-lysine-stimulated kinase that targets the beta2-subunit of AP2. J Biol Chem 280:2153921544. CrossRef Medline

Côté F, Collard JF, Julien JP (1993) Progressive neuronopathy in transgenic mice expressing the human neurofilament heavy gene: a mouse model of amyotrophic lateral sclerosis. Cell 73:35-46. CrossRef Medline

Düwel M, Ungewickell EJ (2006) Clathrin-dependent association of CVAK104 with endosomes and the trans-Golgi network. Mol Biol Cell 17:4513-4525. CrossRef Medline

Eisen JS, Smith JC (2008) Controlling morpholino experiments: don't stop making antisense. Development 135:1735-1743. CrossRef Medline

Ferguson SM, Raimondi A, Paradise S, Shen H, Mesaki K, Ferguson A, Destaing O, Ko G, Takasaki J, Cremona O, O’Toole E, De Camilli P (2009) Coordinated actions of actin and BAR proteins upstream of dynamin at endocytic clathrin-coated pits. Dev Cell 17:811-822. CrossRef Medline

Gieselmann V, Hasilik A, von Figura K (1984) Tartrate-inhibitable acid phosphatase: purification from placenta, characterization and subcellular distribution in fibroblasts. Hoppe Seylers Z Physiol Chem 365:651-660. CrossRef Medline

Gillessen T, Budd SL, Lipton SA (2002) Excitatory amino acid neurotoxicity. Adv Exp Med Biol 513:3-40. Medline

Hallett PJ, Collins TL, Standaert DG, Dunah AW (2008) Biochemical fractionation of brain tissue for studies of receptor distribution and trafficking. Curr Protoc Neurosci Chapter 1:Unit 116.

Hamlin JN, Schroeder LK, Fotouhi M, Dokainish H, Ioannou MS, Girard M, Summerfeldt N, Melançon P, McPherson PS (2014) Scyll scaffolds class II Arfs to specific subcomplexes of coatomer through the gamma-COP appendage domain. J Cell Sci 127:1454-1463. CrossRef Medline

Hara MR, Snyder SH (2007) Cell signaling and neuronal death. Annu Rev Pharmacol Toxicol 47:117-141. CrossRef Medline

Inoue T, Hayashi T, Takechi K, Agata K (2007) Clathrin-mediated endo- 
cytic signals are required for the regeneration of, as well as homeostasis in, the planarian CNS. Development 134:1679-1689. CrossRef Medline

Kanazawa C, Morita E, Yamada M, Ishii N, Miura S, Asao H, Yoshimori T, Sugamura K (2003) Effects of deficiencies of STAMs and Hrs, mammalian class E Vps proteins, on receptor downregulation. Biochem Biophys Res Commun 309:848-856. CrossRef Medline

Kasper D, Dittmer F, von Figura K, Pohlmann R (1996) Neither type of mannose 6-phosphate receptor is sufficient for targeting of lysosomal enzymes along intracellular routes. J Cell Biol 134:615-623. CrossRef Medline

Kok FO, Shin M, Ni CW, Gupta A, Grosse AS, van Impel A, Kirchmaier BC, Peterson-Maduro J, Kourkoulis G, Male I, DeSantis DF, SheppardTindell S, Ebarasi L, Betsholtz C, Schulte-Merker S, Wolfe SA, Lawson ND (2014) Reverse genetic screening reveals poor correlation between morpholino-induced and mutant phenotypes in zebrafish. Dev Cell 32: 97-108. CrossRef Medline

Köster A, Saftig P, Matzner U, von Figura K, Peters C, Pohlmann R (1993) Targeted disruption of the M(r) 46,000 mannose 6-phosphate receptor gene in mice results in misrouting of lysosomal proteins. EMBO J 12: 5219-5223. Medline

Lee DW, Zhao X, Yim YI, Eisenberg E, Greene LE (2008) Essential role of cyclin-G-associated kinase (Auxilin-2) in developing and mature mice. Mol Biol Cell 19:2766-2776. CrossRef Medline

Leist M, Nicotera P (1998) Apoptosis, excitotoxicity, and neuropathology. Exp Cell Res 239:183-201. CrossRef Medline

Liu P, Jenkins NA, Copeland NG (2003) A highly efficient recombineeringbased method for generating conditional knockout mutations. Genome Res 13:476-484. CrossRef Medline

Mangiarini L, Sathasivam K, Seller M, Cozens B, Harper A, Hetherington C, Lawton M, Trottier Y, Lehrach H, Davies SW, Bates GP (1996) Exon 1 of the HD gene with an expanded CAG repeat is sufficient to cause a progressive neurological phenotype in transgenic mice. Cell 87:493-506. CrossRef Medline

McMahon HT, Boucrot E (2011) Molecular mechanism and physiological functions of clathrin-mediated endocytosis. Nat Rev 12:517-533. CrossRef

Meyer C, Zizioli D, Lausmann S, Eskelinen EL, Hamann J, Saftig P, von Figura K, Schu P (2000) mulA-adaptin-deficient mice: lethality, loss of AP-1 binding and rerouting of mannose 6-phosphate receptors. EMBO J 19: 2193-2203. CrossRef Medline

Mitsunari T, Nakatsu F, Shioda N, Love PE, Grinberg A, Bonifacino JS, Ohno H (2005) Clathrin adaptor AP-2 is essential for early embryonal development. Mol Cell Biol 25:9318-9323. CrossRef Medline

Mody M, Cao Y, Cui Z, Tay KY, Shyong A, Shimizu E, Pham K, Schultz P, Welsh D, Tsien JZ (2001) Genome-wide gene expression profiles of the developing mouse hippocampus. Proc Natl Acad Sci U S A 98:88628867. CrossRef Medline

Motley A, Bright NA, Seaman MN, Robinson MS (2003) Clathrin-mediated endocytosis in AP-2-depleted cells. J Cell Biol 162:909-918. CrossRef Medline

Nadler JV, Perry BW, Cotman CW (1978) Intraventricular kainic acid preferentially destroys hippocampal pyramidal cells. Nature 271:676-677. CrossRef Medline

Olney JW (1989) Excitatory amino acids and neuropsychiatric disorders. Biol Psychiatry 26:505-525. CrossRef Medline

Olney JW (1993) Role of excitotoxins in developmental neuropathology. APMIS Suppl 40:103-112. Medline

Peden AA, Rudge RE, Lui WW, Robinson MS (2002) Assembly and function of AP-3 complexes in cells expressing mutant subunits. J Cell Biol 156:327-336. CrossRef Medline

Pelletier S, Julien C, Popoff MR, Lamarche-Vane N, Meloche S (2005) Cy- clic AMP induces morphological changes of vascular smooth muscle cells by inhibiting a Rac-dependent signaling pathway. J Cell Physiol 204:412422. CrossRef Medline

Pelletier S, Gingras S, Funakoshi-Tago M, Howell S, Ihle JN (2006) Two domains of the erythropoietin receptor are sufficient for Jak2 binding/ activation and function. Mol Cell Biol 26:8527-8538. CrossRef Medline

Pelletier S, Gingras S, Howell S, Vogel P, Ihle JN (2012) An early onset progressive motor neuron disorder in Scyl1-deficient mice is associated with mislocalization of TDP-43. J Neurosci 32:16560-16573. CrossRef Medline

Rogers A, Schmuck G, Scholz G, Williams DC (2004) c-fos mRNA expression in rat cortical neurons during glutamate-mediated excitotoxicity. Toxicol Sci 82:562-569. CrossRef Medline

Rogers A, Schmuck G, Scholz G, Griffiths R, Meredith C, Schousboe A, Campiani G, Williams DC (2005) Improvements in an in-vitro assay for excitotoxicity by measurement of early gene (c-fos mRNA) levels. Arch Toxicol 79:129-139. CrossRef Medline

Schmidt O, Teis D (2012) The ESCRT machinery. Curr Biol 22:R116-R120. CrossRef Medline

Schulte-Merker S, Stainier DY (2014) Out with the old, in with the new: reassessing morpholino knockdowns in light of genome editing technology. Development 141:3103-3104. CrossRef Medline

Smeyne RJ, Vendrell M, Hayward M, Baker SJ, Miao GG, Schilling K, Robertson LM, Curran T, Morgan JI (1993) Continuous c-fos expression precedes programmed cell death in vivo. Nature 363:166-169. CrossRef Medline

Sorkin A, Duex JE (2010) Quantitative analysis of endocytosis and turnover of epidermal growth factor (EGF) and EGF receptor. Curr Protoc Cell Biol Chapter 15:Unit 1514.

Tait SW, Green DR (2010) Mitochondria and cell death: outer membrane permeabilization and beyond. Nat Rev 11:621-632. CrossRef Medline

Takeuchi O, Fisher J, Suh H, Harada H, Malynn BA, Korsmeyer SJ (2005) Essential role of BAX, BAK in B cell homeostasis and prevention of autoimmune disease. Proc Natl Acad Sci U S A 102:11272-11277. CrossRef Medline

Tamai K, Toyoshima M, Tanaka N, Yamamoto N, Owada Y, Kiyonari H, Murata K, Ueno Y, Ono M, Shimosegawa T, Yaegashi N, Watanabe M, Sugamura K (2008) Loss of hrs in the central nervous system causes accumulation of ubiquitinated proteins and neurodegeneration. Am J Pathol 173:1806-1817. CrossRef Medline

Terabayashi T, Funato Y, Fukuda M, Miki H (2009) A coated vesicleassociated kinase of $104 \mathrm{kDa}$ (CVAK104) induces lysosomal degradation of frizzled 5 (Fzd5). J Biol Chem 284:26716-26724. CrossRef Medline

Tronche F, Kellendonk C, Kretz O, Gass P, Anlag K, Orban PC, Bock R, Klein R, Schütz G (1999) Disruption of the glucocorticoid receptor gene in the nervous system results in reduced anxiety. Nat Genet 23:99-103. CrossRef Medline

Turgeon B, Meloche S (2009) Interpreting neonatal lethal phenotypes in mouse mutants: insights into gene function and human diseases. Physiol Rev 89:1-26. CrossRef Medline

Wasiak S, Legendre-Guillemin V, Puertollano R, Blondeau F, Girard M, de Heuvel E, Boismenu D, Bell AW, Bonifacino JS, McPherson PS (2002) Enthoprotin: a novel clathrin-associated protein identified through subcellular proteomics. J Cell Biol 158:855-862. CrossRef Medline

Xiang H, Kinoshita Y, Knudson CM, Korsmeyer SJ, Schwartzkroin PA, Morrison RS (1998) Bax involvement in p53-mediated neuronal cell death. J Neurosci 18:1363-1373. Medline

Yamada M, Takeshita T, Miura S, Murata K, Kimura Y, Ishii N, Nose M, Sakagami H, Kondo H, Tashiro F, Miyazaki JI, Sasaki H, Sugamura K (2001) Loss of hippocampal CA3 pyramidal neurons in mice lacking STAM1. Mol Cell Biol 21:3807-3819. CrossRef Medline 